\title{
ROENTGENOLOGICAL STUDY OF SCLEROSIS OF THE TEMPORAL BONE IN CHRONIC OTITIS MEDIA IN RELATION TO ITS COURSE.
}

By

\author{
M. TAJIRI
}

\section{From the Department of Oto-Rhino-Laryngology, Nagasaki University School of Medicine; (Director: Prof. T. Goto)}

One of the controversial problems in the pneumatization study of chronic otitis media is sclerosis of the temporal bone. Regarding this problem we have assumed that sclerosis in chronic otitis media is not due to chronic inflammation of the mucous membrane, but to the individual constitution, based on our study which was carried out histologically. To clarify this problem we must make an observation of the temporal bone roentgenologically during the course of chronic otitis media. So far, this kind of observations has not been reported, because it is a very painstaking work.

For this study the roentgenograms of 831 cases (1033 ears) were taken in Schueller's and Mayer's view. And in 45 cases ( 65 cars) the roentgenograms were taken two or three times in the intervals of one year to ten years.

The results are as follow;

Pneumatization of the temporal bone in chronic otitis media (including cholesteatomaotitis) was under-developed in $87.2 \%$ and well-developed in $12.8 \%$. Attention must be directed to the fact that the well-developed cases were seen in high per centage in this study, because the incidence of the well-developed temporal bone in chronic otitis media was low in the literatures.

Pneumatization in cholesteatoma is underdeveloped in $91.5 \%$ of tympanal type and in $75.6 \%$ of epitympanal type.

In the roentgenogroms of the temporal bones taken two or three times in the forementioned intervals, we could not find any change in these roentgenograms, namely any promoting sclerosis in the temporal bones in the course of chronic otitis media.

Fortunately the roentgenograms of the temporal bones were taken in the two cases of young children of one year old and three years before the ocurrence of chronic otitis media during our study of the development of the air cells in the temporal bone. In these cases the roentgenological observations were repeated in the course of its chronic otitis media, but promotion of sclerosis of the temporal bones was not confrrmed, while a mild development of pneumatization was found in one case.

From these results it must be concluded that sclerosis of the temporal bone seen in chronic otitis media is under-development of pneumatization, not the consequence of inflammation of the pneumatic spaces. 


\title{
慢性中耳炎における側頭骨硬化（Pneumatisations- hemmung) のレ線的時間的追求
}

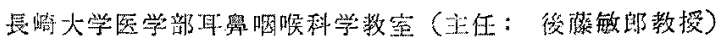

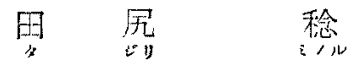

\author{
目次 \\ 1 緒言 \\ 1 锶察材料及び観察方法 \\ 1) 観察标料 \\ a) 慢性中耳炎热渚のPn の総括的睍察 \\ b) 慢性中耳炎鿵者のPn の㭙閒的間隔を和いて \\ の観察 \\ c) 乳幼児慢性中耳炎整者のPnの䋊過を追うて \\ の锶察
}

2) 推察力法
a)「レ」楾攝影法

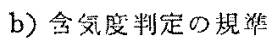

目観察成繶

1) 慢性中耳炎患者のPn の総括的钼察

2) 慢性中耳炎患者のPnの時間的間隔をおいての 観察

3）乳幼児について慢性中耳炎の発症初期からその 経淟を追 5てのPn D観察

IV 考技

1)慢性中耳炎のPn に関する劣按

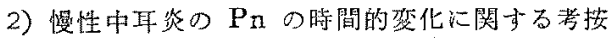

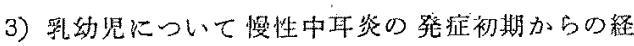

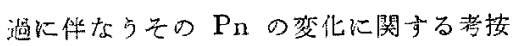

V 総括及び結語

文献

\section{I. 緒言}

現在の含気学説 (Pneumatisationslehre) に打いてな 扣残されてい万重要な問題の 1 つは慢性中耳炎（以下 O.m.c. 亡略守) と含気化抑制 (Pneumatisationshemmung, 以下 Pn.H と記す) との夙係の問題である. 往 涞行われてきた説の 1 つは，侧頭骨のPn-HはO.m.c. の結最起るという説と, 亚の1つは Pn-H それ自身は 体質的遗伝的なもので，か子る側頍骨含気条件 (Pn)の むとに炎症が起ると，その中耳炎は慢性に移行すると云 う説 (Wittmaack) である。

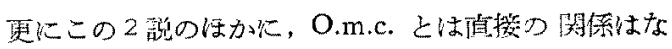

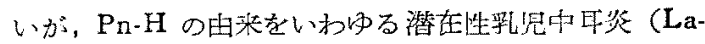
tente Säuglingsotitis) に拉く説 (Wittmaack) が含 気化問題に赫いて重要な位置を占めていた。この訪の有 力たために，第 1 の O.m.c. によつて Pn-H が起ると いう説は，それ自体は明確な形態学的証明を欠くにも拘

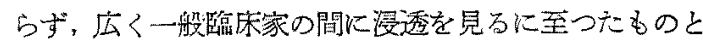

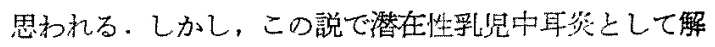
釈されていた組織現象は，最近漸々，側頙骨に含気化 (Pneumatisation, 以下 Pn と記子) 计起ることのため に現れる生理的現秋に逗ぎないと見做されるに至つた

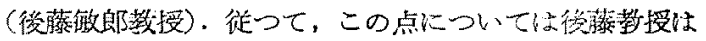
Pn-H なる現象は孚児期の潜在性中耳奖によるもので なく林質的遗伝的なものであるとする Albrecht の作 筫説に筫成したことになる。

O.m.c. とPn-H 即ち側頭骨硬化との䦭係は，これら の閔題とに別個の問題であるが，一般ては而者混同して 涪えられる傾问にあり，そのために，O.m.c. 患者にし

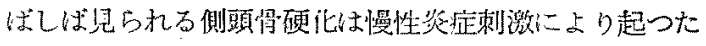
むのであると涾ぜられる結果をきたしたるのと思われ

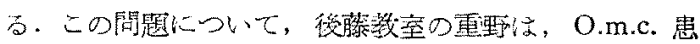

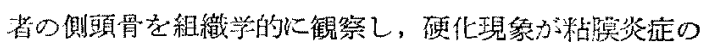
ために起つているといら所見を認めるこにができなかつ ネと述ベている。しかし，O.m.c. によつて傾骨挭化 か起ることは全くないかいらと，これを明確に否定す ることは組織学的所罢のみからでは不可能なことであ る.この閴に最後的な解明を与えるむのは，O.m.c. 舁者個人の経避に良つて時間的に Pn の复仁を追求す

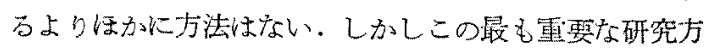

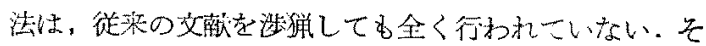

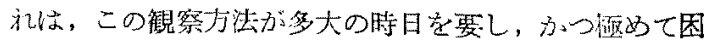

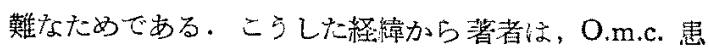

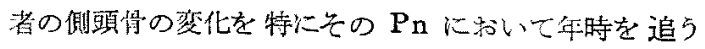
て観察することを本研究の目的とした。

即ら，この研究を行らにあたつて，次の了項目にわた 


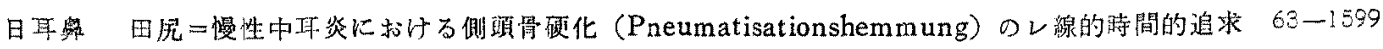

つて鼬祭した。

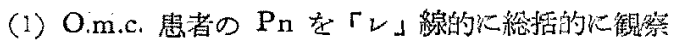
した。

(2) O.m.c. 患者の Pn を時間的間隔势おいて2 回以 上能察比較した。

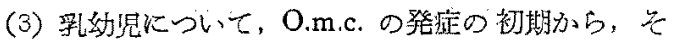
す経過を追うてPn を観察した。

以上了項目につき観察した結果，この問題について 2、3の知見を得たので報告する。

\section{II. 観察材料及び観察方法}

(1) 観祭材料

a) O.m.c. 患者の Pn の総括的観案：この目的のた わに，昭和 23 年以降同 34 年索での 12 利間に長大医学

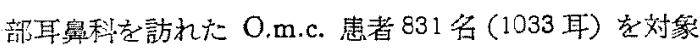
として，「レ小線観察を行つた，年令は0禾11 力月より

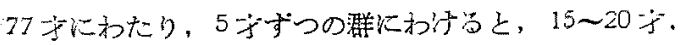
20ー25才の支最多多つた，性別では罗子494台，

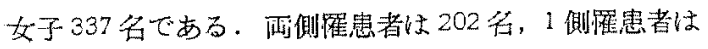

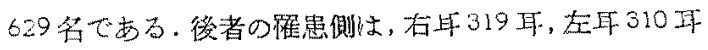

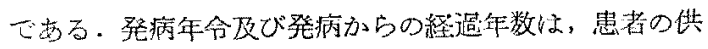

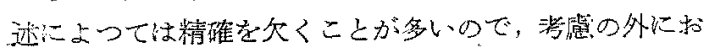
い去。

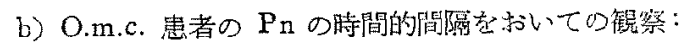
この目的のために，同期間に長大医学部耳率科及び国立 嬉野病院耳鼻科を訪れた O.m.c. 整者の5方，2回以上 数回「レ」線趣影を行い得た 45 名 65 耳を刘象とした。 内訳男子 27 名，女子18各，右耳32，左耳33です

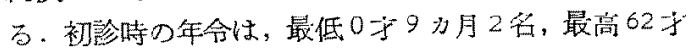

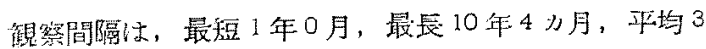

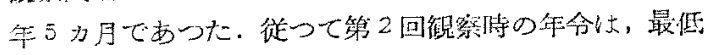

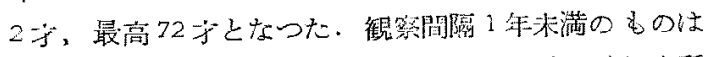

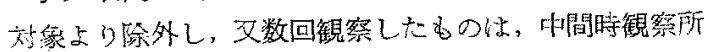
㫕を参考として，最初之最後の所胃を比較梌討した。

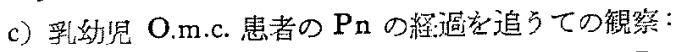

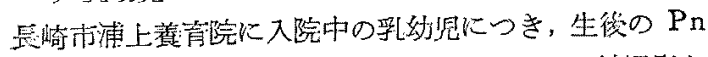
の発青研究のため，昭和27年以降每年，「レ」總㵊影を

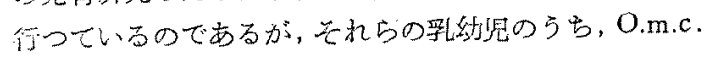

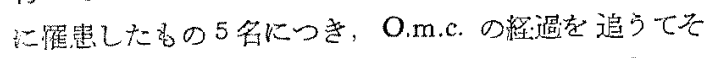

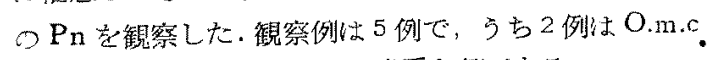

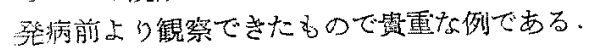

(2) 観祭方法

a)「レ」線撮影法：耳の「レ』袙撮影法としては，

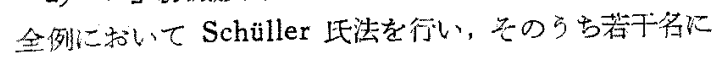

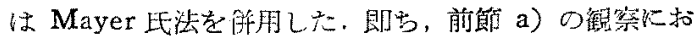

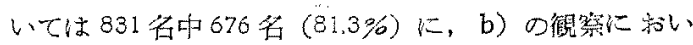

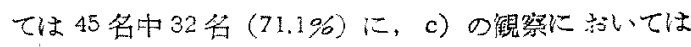
5 名全例心，Schüller 戌法と Mayer 氏法を作用し， 各䗋虽の钼祭の精確老期した。

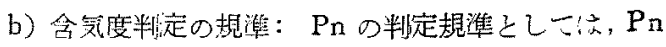
発肖度比較に鼠与適しているため, 後藤敏部孝授の分類

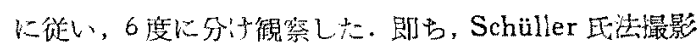

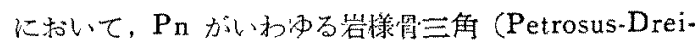

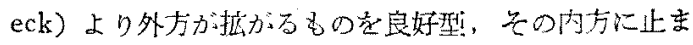
るものを㧕制型とし，そのおのおのを更にる祀分つ

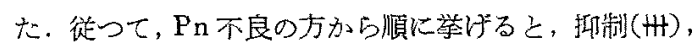
间 $(H)$, 同 $(t)$, 良好 $(t)$, 同 $(H)$, 同 $(H)$ ) 型 となる。良好（十）上坜制（十）の如く，明確な境界を決

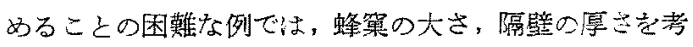
虑して半婹した。

\section{III. 観察成樍}

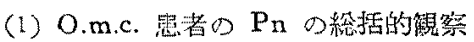

表14。831台1038耳. O.m.c. を, 単純性 O.m.c.,

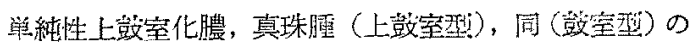

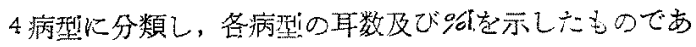
万. 即占，単純性O.m.c. 1910 耳 $(88.1 \%)$ ，算純性

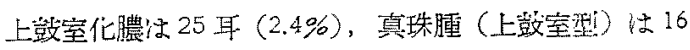

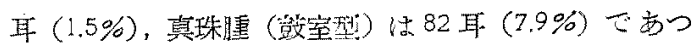
た。

表 1 漫性山耳炎の病型別耳数

\begin{tabular}{|c|c|c|c|c|}
\hline 病型 & \multicolumn{2}{|c|}{ 军数 } & \multicolumn{2}{|c|}{$\%$} \\
\hline 单綿性慢性中互炎 & \multicolumn{2}{|c|}{910} & \multicolumn{2}{|l|}{88.1} \\
\hline 单能性上鼓案化裳 & 25 & \multirow{2}{*}{41} & 2.4 & \multirow{2}{*}{40} \\
\hline 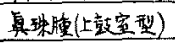 & 18 & & 1.5 & \\
\hline 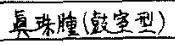 & \multicolumn{2}{|l|}{82} & \multicolumn{2}{|l|}{7.9} \\
\hline 言 & \multicolumn{2}{|l|}{1033} & \multicolumn{2}{|l|}{100.0} \\
\hline
\end{tabular}

表2は，O.m.c. 全体として覞察した Pn の灯態を示 したもので，抑制(H)は 470耳. $(45,4 \%)$ ，同(H)は 323 耳 $(31.3 \%)$, 同 $(+) 108$ 年 $(10.5 \%)$ ，度好 $(t)$ 《55耳 $(5.3 \%)$, 同(H)心 50 耳 $(4.8 \%)$, 同(H)は

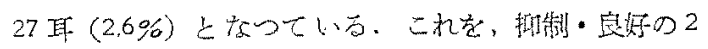

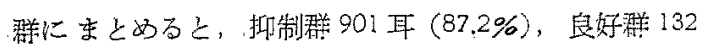

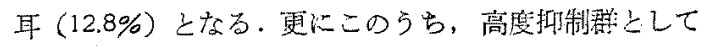

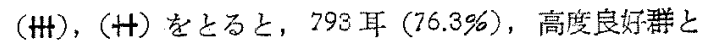
して (H)，(H) をとると77耳 $(7.4 \%)$ となる。 


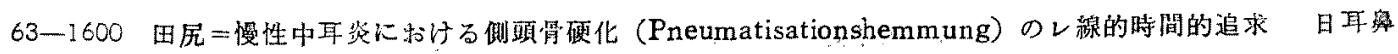

表 2 慢性中耳炎全体としての Pn

\begin{tabular}{|c|c|c|c|c|c|c|c|}
\hline \multirow{2}{*}{$P_{n}$} & \multicolumn{3}{|c|}{ 择制 } & \multicolumn{3}{|c|}{ 泉好 } & \multirow[b]{2}{*}{ 計 } \\
\hline & H4 & + & + & + & ++ & $\mathrm{HH}$ & \\
\hline \multirow{2}{*}{$\begin{array}{l}\text { 全 } \\
\text { 悝 } \\
\text { 坚 } \\
\text { 中 } \\
\text { 咠 }\end{array}$} & 470 & 323 & 108 & 55 & 50 & 27 & \multirow[t]{2}{*}{1033} \\
\hline & \multicolumn{3}{|c|}{901} & \multicolumn{3}{|c|}{132} & \\
\hline \multirow{2}{*}{$\%$} & 45.4 & 31.8 & 10.5 & 5.3 & 4.8 & 2.6 & \multirow{2}{*}{100} \\
\hline & \multicolumn{3}{|c|}{872} & \multicolumn{3}{|c|}{8} & \\
\hline
\end{tabular}

表了は，笔純性 O.m.c.のPn の状態起示したもの

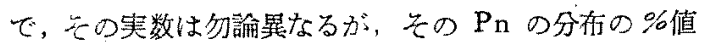

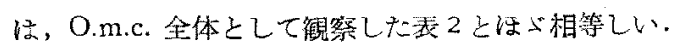

表 3 新純性慢性中正炎（鼓室型）のPn

\begin{tabular}{|c|c|c|c|c|c|c|c|}
\hline \multirow{2}{*}{$P_{n}$} & \multicolumn{3}{|c|}{ 抑制 } & \multicolumn{3}{|c|}{ 息好 } & \multirow{2}{*}{ 計 } \\
\hline & H & $\#$ & + & + & + & H & \\
\hline \multirow{2}{*}{ 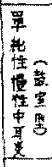 } & $4 / 4$ & 280 & 101 & 49 & 42 & 24 & \multirow{2}{*}{910} \\
\hline & \multicolumn{3}{|c|}{795} & \multicolumn{3}{|c|}{115} & \\
\hline$\%$ & 45.5 & 30.8 & 11.1 & 5.4 & 4.6 & 2.6 & \multirow{2}{*}{100} \\
\hline$\%$ & & 87.4 & & & 12. & & \\
\hline
\end{tabular}

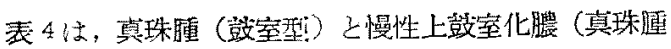
上鼓室型を含む）とのPn の状態を示したるのである。

表 4 真珠腫（鼓室型）及び慢性上鼓室炎 (含上鼓室型真碀腄) $\odot \mathrm{Pn}_{\mathrm{n}}$

\begin{tabular}{|c|c|c|c|c|c|c|c|}
\hline \multirow{2}{*}{ Fn } & \multicolumn{3}{|c|}{ 抑 制 } & \multicolumn{3}{|c|}{ 良好 } & \\
\hline & $+H$ & + & + & \pm & + & + & \\
\hline \multirow{2}{*}{ 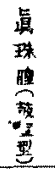 } & 40 & 31 & 4 & 3 & 3 & 1 & \multirow{2}{*}{82} \\
\hline & \multicolumn{3}{|c|}{75} & \multicolumn{3}{|c|}{7} & \\
\hline \multirow{2}{*}{$\%$} & 48.8 & 3788 & 4,9 & 3.7 & 3.7 & 1.2 & \multirow{2}{*}{100,0} \\
\hline & \multicolumn{3}{|c|}{945} & \multicolumn{3}{|c|}{8.5} & \\
\hline \multirow{2}{*}{ 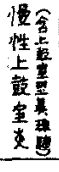 } & 16 & 12 & 3 & 3 & 5 & 2 & \multirow[t]{2}{*}{41} \\
\hline & \multicolumn{3}{|c|}{31} & \multicolumn{3}{|c|}{10} & \\
\hline \multirow{2}{*}{$\%$} & 390 & 29.3 & 7.3 & 7.3 & 12.2 & 49 & 100.0 \\
\hline & \multicolumn{3}{|c|}{75.6} & \multicolumn{3}{|c|}{24.4} & \multirow{3}{*}{123} \\
\hline \multirow{4}{*}{ it } & 56 & 43 & 7 & 6 & 8 & 3 & \\
\hline & \multicolumn{3}{|c|}{106} & \multicolumn{3}{|c|}{17} & \\
\hline & 45.5 & 350 & 57 & 4.9 & 6.5 & 2.4 & \multirow{2}{*}{100.0} \\
\hline & \multicolumn{3}{|c|}{-86.2} & \multicolumn{3}{|c|}{13.8} & \\
\hline
\end{tabular}

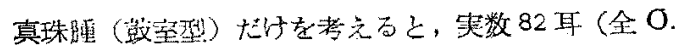
m.c. $97.9 \%$ ) の5b. 抑制 (H) 40 耳 (48.8\%), 同 (H) 31 耳 $(37.8 \%)$, 同 $(t) 4$ 耳 $(4.9 \%)$, 良好 $(+) 3$ 耳 $(3.7 \%)$, 同(H) 3 耳 $(3.7 \%)$, 同 (H) 1 耳 $(1.2 \%)$

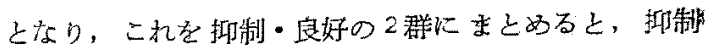
72 耳 $(91.5 \%)$ ，良好7早 $(8.5 \%)$ となる. 更にこのう ち、高度抑制として（H）（H）をとると71耳(86.6 \%)，高度良好鸿之して（H）（H）をとると4耳（4.9 \%) となる.

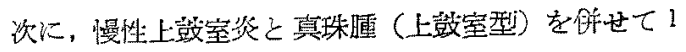

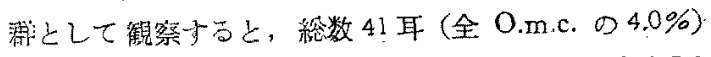
の5b，斯制(H) 16 耳 (39.0\%), 同 (H) 12 耳 $(29.3$ \%), 同 $(+) 3$ 耳 $(7.3 \%)$, 良好 $(+) 3$ 耳 $(7.3 \%)$, 同 (H) 5 耳 $(12.2 \%)$, 同 (H) 2 耳 $(4.9 \%)$ で, これ学脚 制・良好の 2 群心ま之めると, 抑制 31 耳 $(75.6 \%)$, 良

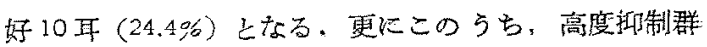
として (H)，(H)をとると28耳 $(68.3 \%)$ ，高度庭好 として $(H)$ ，(州)をとると7耳 $(17.19 \%)$ となる。

臹 5 は，一僛性 O.m.c. (全病型) 㭧者629名につき,

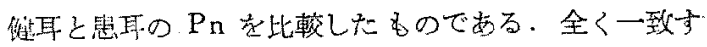
万るのは，麦の左上より右下にわたり二重舶它もつて囲 まれた闌内に示的，合計 156 耳 $(24.8 \%)$ となる。

表 5 一侧慢性中耳炎 (企病型) 程虫群の Pno雨晋比較

\begin{tabular}{|c|c|c|c|c|c|c|c|c|c|}
\hline \multirow{2}{*}{\multicolumn{2}{|c|}{ 健虫侧 }} & \multicolumn{3}{|c|}{ 抑制 } & \multicolumn{3}{|c|}{ 良好 } & \multirow{2}{*}{$t$} & \multirow{2}{*}{$\%$} \\
\hline & & +4 & \# & + & + & $\mathrm{HI}$ & 㖼 & & \\
\hline & HIT & 56 & 5 & 3 & 0 & 0 & 0 & 64 & 10.2 \\
\hline & $\#$ & 32 & 45 & 6 & $3 j$ & 0 & 0 & 86 & 13.8 \\
\hline & + & 25 & 33 & 6 & 2 & 2 & 0 & 68 & 10.8 \\
\hline \multirow{3}{*}{ 良 } & + & 32 & 34 & 17 & 13 & 2 & 0 & 98 & 15.6 \\
\hline & H & 57 & 52 & 21 & 14 & 17 & 3 & 164 & 26.1 \\
\hline & int & 54 & 41 & 18 & 5 & 12 & 19 & 149 & 23.7 \\
\hline \multicolumn{2}{|c|}{ 敦 } & 256 & 210 & $7 /$ & 37 & 33 & 22 & 629 & 100.0 \\
\hline & $\%$ & 60 ? & 334 & 41.3 & 5.9 & 5.2 & 3.5 & 100.0 & \\
\hline
\end{tabular}

敏側のPnは, 抑制 $(H) 256$ 耳 $(40.7 \%)$, 同 $(H)$ 210 耳 $(33.4 \%)$, 同 (十) 71 耳 $(11.3 \%)$, 良好 $(+) 37$ 耳 $(5.9 \%)$, 同 (H) 33 耳 $(5.2 \%)$, 同 (H) 22 耳 (3.5\%) である。

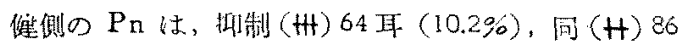
耳 $(13.8 \%)$, 网 $(+) 68$ 耴 $(10.8 \% 0)$, 良好 $(+) 98$ 耳 (15.6\%), 同 (H) 164耳 (26.1\%), 同 (H) 149 耳 (23.7

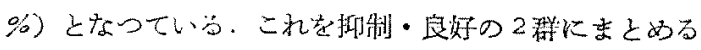
之，抑制218耳 $(34.7 \%)$ ，良抿 411 耳 $(65.3 \%)$ となる。

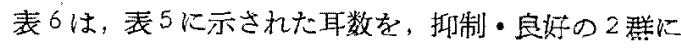
まとるて示したものである。即ら，〔獲側抑制一患側坜 制】 211 耳 $(33.5 \%)$ ，〔低側良好一患側良好〕群 85 


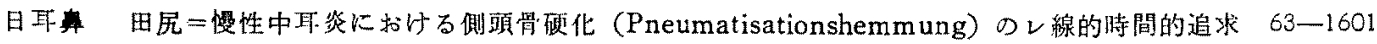

耳 (13.5\%), 合計して Pn 一致せるむ。296 耳 $(47.0$

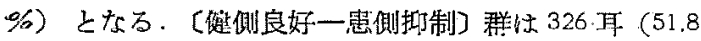

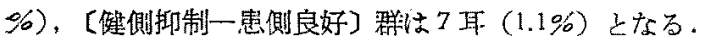

表 6 㧕制・良好2群に分けての锶察

\begin{tabular}{|c|c|c|c|}
\hline 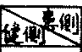 & 仰 & 这好。 & 壾 \\
\hline 抑制 & 211 & 7 & $2 / 8$ \\
\hline$\%$ & $(33.5)$ & (1.1) & $(34.7)$ \\
\hline Et & 326 & 85 & 411 \\
\hline$\%$ & $(51.8)$ & $(13.5)$ & $(65.3)$ \\
\hline 害市 & 537 & 92 & 629 \\
\hline$\%$ & $(85.4)$ & $(14.6)$ & $(100.0)$ \\
\hline
\end{tabular}

左右一致度 $=296$ 耳/629 耳 $=47.0 \%$

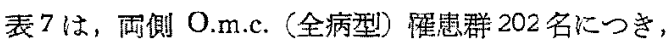

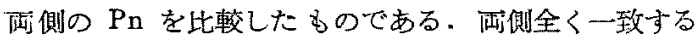

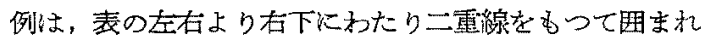
广榴内に示され，合計 134 例 $(66.3 \%)$ となる。 不一玫

表 7 两侧慢性中耳炎（全病型）准患群の Pn の左右比較

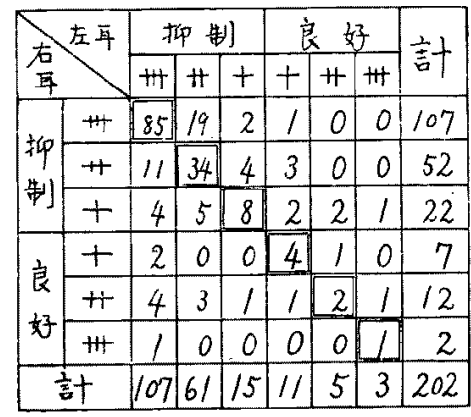

左右一致度 $=134$ 例 $/ 202$ 例 $=66.3 \%$

例の合計は68例 (33.7\%) となる（表8のA).この一 玫例計 134 例を, てのPn の程度ごに区分して示す 上, 表 8 の B の如く, 抑制 (H) 85 例 $(63.4 \%)$, 同(H) 34 例 $(25.4 \%)$, 同 (十) 8 例 $(6.0 \%)$, 良好 (十) 4 例 $(3.0 \%)$, 同 (H) 2 例 $(1.5 \%)$, 同 (H) 1 例 $(0.7 \%)$ て 如制・良好の2 群にまとめ万と，抑制群杜 127 例 (94.8 $\%$ ，良好例は7例 $(5.2 \%)$ となる。

表 $80 \mathrm{~A}$ 、乘側慢性中耳炎 (全病型) の $\operatorname{Pn}$ の左在比較

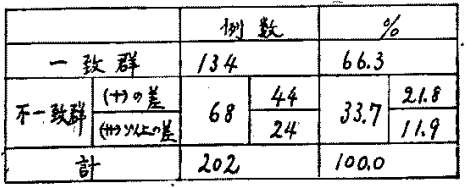

表 8 の. 一致群のPn

\begin{tabular}{|c|c|c|c|c|}
\hline \multicolumn{2}{|c|}{$P_{n}$} & 数 & $-\%$ & 計 \\
\hline \multirow{3}{*}{$\begin{array}{l}\text { 卯 } \\
\text { 制 }\end{array}$} & tH & 85 & 63.4 & \multirow{3}{*}{948} \\
\hline & $\pi$ & 34 & 25.4 & \\
\hline & + & 8 & 6.0 & \\
\hline \multirow{3}{*}{$\begin{array}{l}\text { 良 } \\
\text { 好 }\end{array}$} & + & 4 & 3.0 & \multirow{3}{*}{5.2} \\
\hline & + & 2 & 1.5 & \\
\hline & HI & 1 & 0.7 & \\
\hline \multicolumn{2}{|c|}{ 計 } & 134 & 100.0 & 100.0 \\
\hline
\end{tabular}

表8のC. 不一致群のPn 左右差

\begin{tabular}{|c|c|c|c|c|}
\hline 差程 & 数 & & $\%$ & \\
\hline 1 莫美 & 44 & & 64.8 & \\
\hline 2度表 & 12 & \multirow{4}{*}{24} & 17.6 & \multirow{4}{*}{35.2} \\
\hline 3度差 & 7 & & 10.3 & \\
\hline 4度差 & 4 & & 5.9 & \\
\hline 5度差 & 1 & & 1.4 & \\
\hline 言十 & 68 & & 100.0 & \\
\hline
\end{tabular}

表 8 のC は, 攵の不一致例棓 68 例を, そのPn

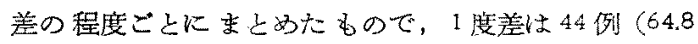
$\%), 2$ 度差以上性 24 例 $(35.2 \%)$ となる。

表9は，この Om.c.忠者のPn の総括的钼寗の対象 とした1033耳のう，Pn 良好なるもの」\%を，各年 度に分けて示したものである，全例のうちPn 良好な るもの土比率は，12.8\%となつているが，各年度によけ るとれは，最高昭和 23 年の $27.8 \%$ ，最低炤和 34 年の $6.7 \%$ で，各年度ことに何らの傾问も見られない。

表 9 慢性中耳炎罪患耳にしてPn 底好 なるるの>逐年推移

\begin{tabular}{|c|c|c|c|c|c|c|c|}
\hline \multirow{2}{*}{ 年 } & \multirow[b]{2}{*}{ 患者数 } & \multirow[b]{2}{*}{ 忠偻 } & \multicolumn{3}{|c|}{ Pn良好 } & \multicolumn{2}{|l|}{ 敦 } \\
\hline & & & + & $H$ & $H$ & & $\%$ \\
\hline 23 & 31 & 36 & 4 & 6 & 0 & 10 & $2 \pi .8$ \\
\hline 24 & 65 & 74 & 5 & 1 & 0 & 6 & 8.1 \\
\hline 25 & 39 & 44 & 2 & 0 & 1 & 3 & 6.8 \\
\hline 26 & 66 & 83 & 9 & 3 & 1 & 13 & 15.7 \\
\hline 27 & 52 & 63 & 5 & 5 & 2 & 12 & 19.0 \\
\hline 28 & 49 & 58 & 2 & 3 & 2 & 7 & 12.1 \\
\hline 29 & 91 & 118 & 5 & 3 & 7 & 15 & 12.7 \\
\hline 30 & 81 & 112 & 3 & 4 & 2 & 9 & 8.0 \\
\hline 31 & 65 & 80 & 1 & 4 & 1 & 6 & 7.5 \\
\hline 32 & 96 & 121 & 3 & 8 & 3 & 14 & 11.1 \\
\hline 33 & 98 & 126 & 12 & 9 & 8 & 29 & 23.1 \\
\hline 34 & 98 & 118 & 4 & 4 & 0 & 8 & 6.7 \\
\hline 計 & 831 & 1033 & 55 & 50 & 27 & 132 & 12.8 \\
\hline
\end{tabular}




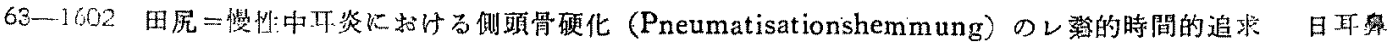

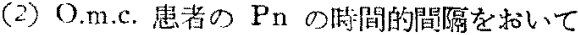
の舀察

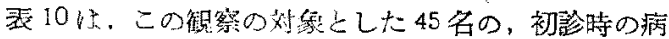
名を示したものである。.m.c.は、右耳 32 耳, 左耳 33 耳に見られ，この合計65耳本䃆祭の対像とした。

表 10 初街時讋断

\begin{tabular}{|c|c|c|c|c|c|}
\hline & 慢性中联 & 急性中耳湿 & 联猪害症 & 正常 & 鼓 \\
\hline 碷 & 32 & 2 & 2 & 9 & 45 \\
\hline 在耳 & 33 & 2 & 1 & 9 & 45 \\
\hline 壾 & 65 & & & & \\
\hline
\end{tabular}

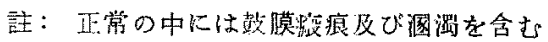

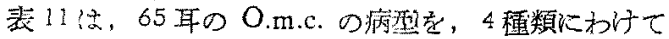
示したものである、即る，蒴純性 O.m.c. は49耳 (75.3

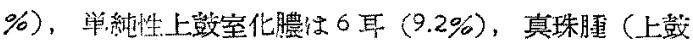

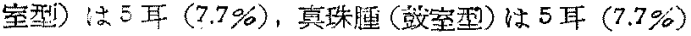

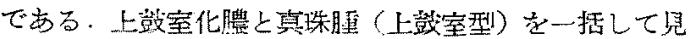
るட11 耳. $(16.996)$ Łなる。

表 11 慢性中耳焱の病型別耳数

\begin{tabular}{|c|c|c|}
\hline 苪 型 & 岁数 & $\%$ \\
\hline 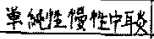 & 49 & 75.3 \\
\hline 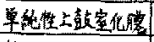 & 6 & 9.2 \\
\hline 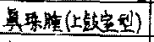 & 5 & 7.7 \\
\hline 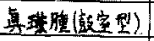 & 5 & 77. \\
\hline 站 & 65 & 1000 \\
\hline
\end{tabular}

表 12 は，本锶察の第1 回目の時の患耳のPn 者 病们ごとに示したものである。各病型を通じてPnを まとめる之，抑制（H）15 耳 (23.1\%)，同 (H) 26 耳 $(40 \%)$ ，同 (t)16 耳. $(24.6 \%)$ ，良好 $(+) 5$ 耳 $(7.7 \%)$, 同 $(H) 1$ 耳: $(1.5 \%)$, 同 (H) I 耳 $(1.5 \%)$ となつてい

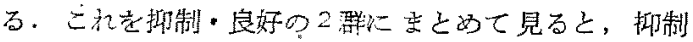
57 耳 $(87.7 \%)$ ，良好 7 耳 $(10.8 \%)$ となつている。これら

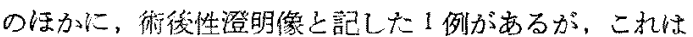
既往に手術をらけていながら初診時なお耳瀮のあつたる のである。

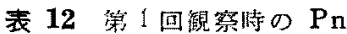

\begin{tabular}{|c|c|c|c|c|c|c|c|c|c|}
\hline \multirow{2}{*}{\multicolumn{2}{|c|}{ 疾恕别 }} & \multicolumn{3}{|c|}{ 㨨掣 } & \multicolumn{3}{|c|}{ 主好 } & \multirow{2}{*}{ 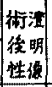 } & \multirow{2}{*}{ 塾 } \\
\hline & & $H$ & H & + & + & $H$ & 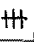 & & \\
\hline \multicolumn{2}{|c|}{ 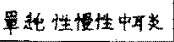 } & 9 & 21 & 12 & 5 & 1 & 1 & & 49 \\
\hline \multicolumn{2}{|c|}{ 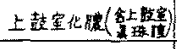 } & 5 & 4 & 2 & & & & & 11 \\
\hline \multicolumn{2}{|c|}{ 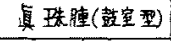 } & 1 & 1 & 2 & & & & I & 5 \\
\hline \multirow{4}{*}{ 計 } & & 15 & 26 & 16 & 5 & 1 & 1 & 7 & \multirow{2}{*}{65} \\
\hline & & & 57 & & & 7 & & 1 & \\
\hline & \multirow[b]{2}{*}{$\%$} & & 40.0 & 24.6 & 7.7 & 1.5 & 1.5 & 1.5 & \multirow{2}{*}{100.0} \\
\hline & & & 87 & & & 0.8 & & 1.5 & \\
\hline
\end{tabular}

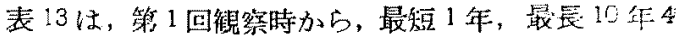

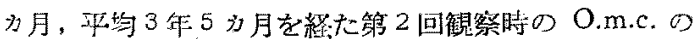
病型と，艺の第 1 回锶察との比較を示したものである。 即ち，単.純性 O.m.c. 49 耳のうち2耳が真珠通（晋室

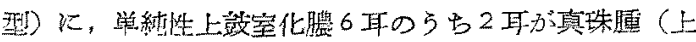

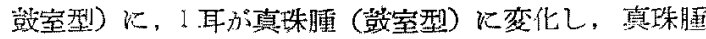

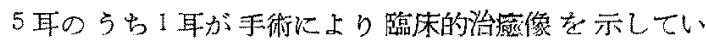

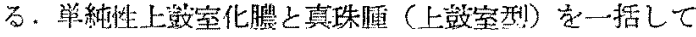

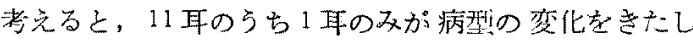
たことになる。

表 13 病 型 $の$ 变 化

\begin{tabular}{|c|c|c|c|c|}
\hline 病型 & 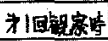 & 化化俄 & \multicolumn{2}{|c|}{ 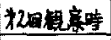 } \\
\hline 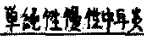 & 49 & & & 47 \\
\hline 单纯住上䞚定化缕 & 10 & & 3 & 10 \\
\hline 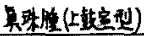 & 11 & & & \\
\hline 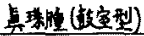 & 5 & & & 7 \\
\hline 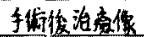 & & & & 1 \\
\hline 㝇 & 65 & (6) & & 65 \\
\hline
\end{tabular}

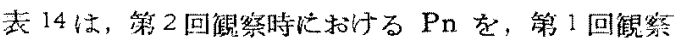

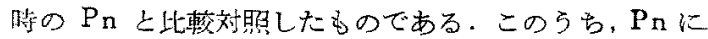
全く変化の見られなかつた例数は，表の左右から右下に かけて二量線を星つて国まれた闌内に示され，その合計 は48耳 (73.8\%)である.変化したものは，抑制(H)

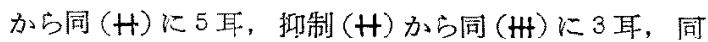
(H) 加同 (t)k3耳, 抑制 $(+)$ 加同 $(H) k 1$ E, 阁(十)加网 (H)k3耳で, 計 15 耳 (23.1\%)にな

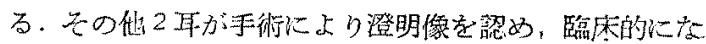
怙耳漏があつた。

表 14 策 2 回钼察時におけるPn の变化

\begin{tabular}{|c|c|c|c|c|c|c|c|c|c|c|}
\hline \multirow{2}{*}{\multicolumn{3}{|c|}{ 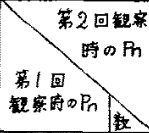 }} & \multicolumn{3}{|c|}{ 抑 制 } & \multirow{2}{*}{ 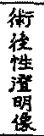 } & \multicolumn{3}{|c|}{ 良好 } & \multirow{2}{*}{ 壾 } \\
\hline & & & H & H & + & & + & H & - \# & \\
\hline \multirow{3}{*}{ 制 } & +\#t & 15 & 9 & 5 & & 1 & & & & 15 \\
\hline & + & 26 & 3 & 20 & 3 & & & & & 26 \\
\hline & + & 16 & 1 & 3 & 11 & $1^{*}$ & & & & 16 \\
\hline \multicolumn{2}{|c|}{ 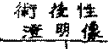 } & 1 & & & & 1 & & & & 1 \\
\hline \multirow{3}{*}{$\begin{array}{l}\text { 良 } \\
\text { 㐨 }\end{array}$} & + & 5 & & & & & 5 & & & 5 \\
\hline & $H$ & 1 & & & & & & 1 & & 1 \\
\hline & $\mathrm{HH}$ & 1 & & & & & & & 1 & 1 \\
\hline \multicolumn{3}{|c|}{ 㖕 } & 13 & 28 & 14 & 3 & 5 & i & 1 & 65 \\
\hline
\end{tabular}

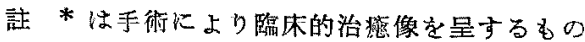




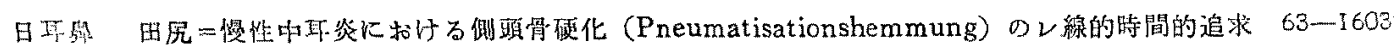

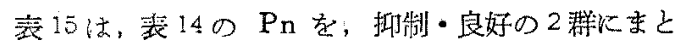
めたもので, 㐿術例以外，Pn の奖化结全く認められな W.

表 15 抑制・良好 2 群に分HてのPn の奖化

\begin{tabular}{|c|c|c|c|c|c|}
\hline$\pi 180$ & $3^{2}$ & 抑糟了 & 良好 & 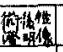 & 部 \\
\hline 树制 & 57 & 55 & 0 & 2 & 57 \\
\hline 好 & 7 & 0 & 7 & & 7 \\
\hline then & 1 & & & 1 & 1 \\
\hline st & 65 & 55 & 7 & 3 & 55 \\
\hline
\end{tabular}

(3) 乳奻居以ついて O.m.c. の 発症初期方らとの経遗を追 5 七の $\operatorname{Pn}$ の観察

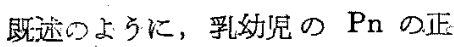
管登育宾追うて経避観察中に，O.m.c.

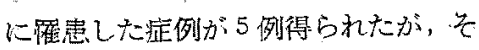

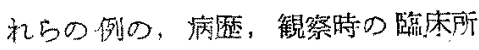

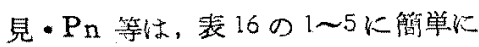
示した。表の各闑は, 左万加, 観案 時 (年令)，病麾及び䧗床所晃，Pn, 管

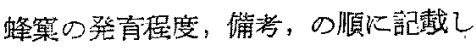
た。蜂笨の発去程度の闌の、 $\mathbf{S}$ は䚬部 䗋䆵，Wは隅角蜂巢，PはS字状洞 周国䗋窧を示している。

以下, 各症例以つき経遇を述べる。

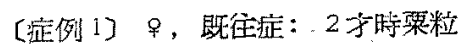
結核にて1年半入院加療， 3 子 3 月

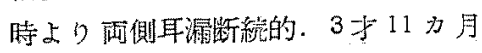

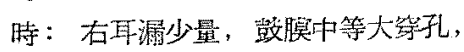

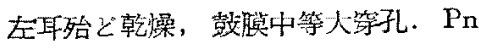
は右抑制(十)，左抑制(十)，4安 11

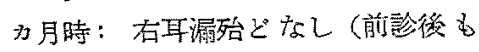
耳漏が時方少つた，鼓娦中等大穿孔。

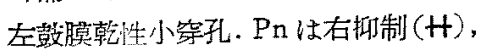

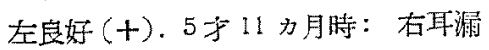
中等量，鼓䐺案孔や>大，大敖脱乾性

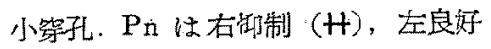
(十). 7時：右耳㵊1力月前上り

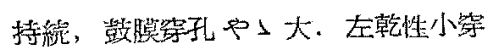

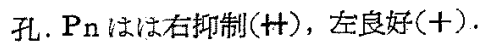
8才時：右耳漏殆ど挡続，豉臊大穿 孔. 左乾性小鸡孔.Pn 恃右抑制(H); 左良好 $(+)$ 。即b， 4 年の経過期間を

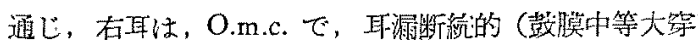

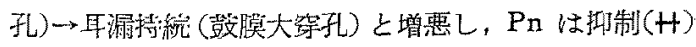
のま〉変化していない，各蜂巢につき見るとSは(士) $( \pm) \rightarrow( \pm) \rightarrow(-) \rightarrow( \pm), \mathbf{W}$ は, $(-) \rightarrow( \pm) \rightarrow( \pm) \rightarrow$ $( \pm) \rightarrow( \pm), \mathbf{P}$ :,$(-) \rightarrow(-) \rightarrow(-) \rightarrow(-) \rightarrow(-)\llcorner$

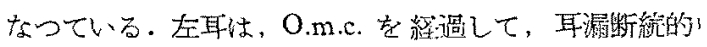

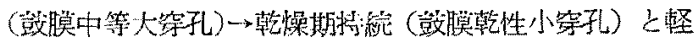

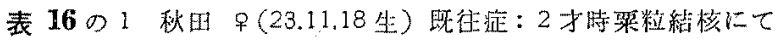

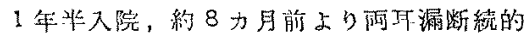

\begin{tabular}{|c|c|c|c|c|c|}
\hline \multirow{2}{*}{$\begin{array}{l}27-10-22 \\
(3 \times 1104)\end{array}$} & \multirow{2}{*}{ 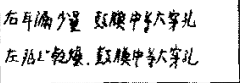 } & 右招判( & $S(t) W(\leftrightarrow P$. & P.t & \\
\hline & & 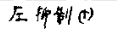 & $S_{2}(t) \quad W(t) \quad D$ & $P(-)$ & 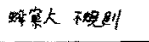 \\
\hline \multirow{2}{*}{$\begin{array}{l}28-10-5 \\
(4 \lambda / 10 A)\end{array}$} & \multirow{2}{*}{ 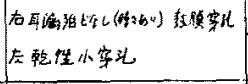 } & 右们制( & $S(t) \quad W_{1}(t) \quad P$ & $P_{1}(-)$ & \\
\hline & & 压良好(t) & $S(t) \quad W(t) P$ & $P_{.}(t)$ & 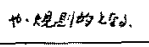 \\
\hline \multirow{2}{*}{$\begin{array}{l}29-10-6 \\
(5 \times 11+A)\end{array}$} & \multirow{2}{*}{ 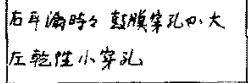 } & 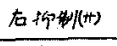 & $S( \pm) W( \pm) P$ & $P(\leftrightarrow)$ & \\
\hline & & $\sqrt{x} \mathrm{Q}_{\mathrm{C}}$ & $S_{1}(t) w(t) p$ & $p(t)$ & \\
\hline \multirow{2}{*}{$\begin{array}{c}30+11-17 \\
(7 t)\end{array}$} & \multirow{2}{*}{ 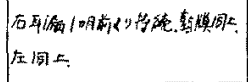 } & 右抑舴(+*) & $\left.S_{1} \leftrightarrow W_{(}\right) \quad P$ & P. & \\
\hline & & 厌良 $\theta(+)$ & $S(t) W(r) P$ & $P_{i}(t)$ & $s \times b a$ \\
\hline \multirow{2}{*}{$\begin{array}{c}31-11-30 \\
(8 t)\end{array}$} & \multirow{2}{*}{ 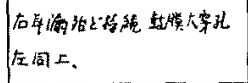 } & 右构制(r) & $S$ (I) $\quad v,( \pm) \quad P$ & $P(\rightarrow)$ & \\
\hline & & 在宏好(t) & $S(t) \quad W_{1}(t) \quad P_{0}$ & $P_{0}(t)$ & S拻大。 \\
\hline
\end{tabular}

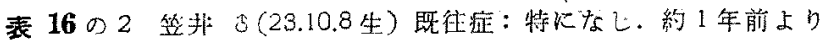

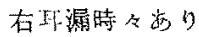

\begin{tabular}{|c|c|c|c|c|c|c|}
\hline \multirow{2}{*}{$\begin{array}{l}27-10-22 \\
(4 \lambda)\end{array}$} & \multirow{2}{*}{ 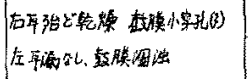 } & 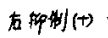 & $S .(+)$ & $w(t)$ & $P, \leftrightarrow$ & 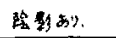 \\
\hline & & 在离好心 & $S .(+1)$ & W. $(\rightarrow)$ & $P(t)$ & \\
\hline \multirow{2}{*}{$\begin{array}{l}29-10-5 \\
(5 t)\end{array}$} & \multirow{2}{*}{ 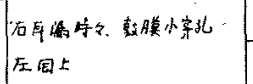 } & 右良好(十) & S.(T) & $\omega, \leftrightarrow$ & $P_{0}(t)$ & 生察敌明 \\
\hline & & 厌家好( & $S(t+)$ & $W(+)$ & $P(t)$ & $P=0$ tht. \\
\hline \multirow{2}{*}{$\begin{array}{c}29-10-6 \\
(6 \pm)\end{array}$} & \multirow{2}{*}{ 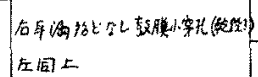 } & 后良好( & $S_{.}(+1+1)$ & $W(t)$ & $p_{(r)}$ & 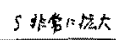 \\
\hline & & 左良好(H) & $S(++)$ & $w,(t)$ & $P(t)$ & 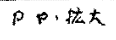 \\
\hline
\end{tabular}

表 16 の3 浦由。(25.5.11生) 既往症：特になし.1 年半前より 雨侧耳漏特々支り，現在はない

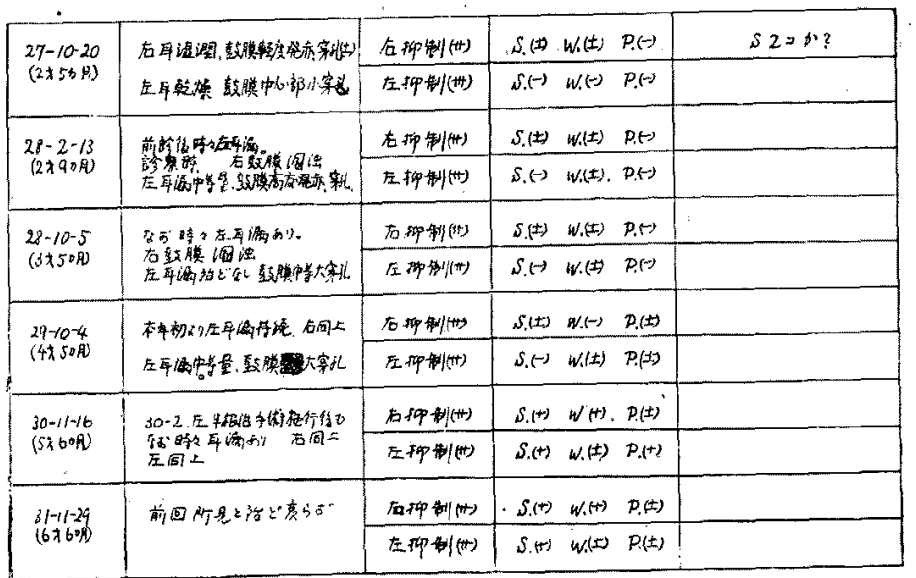




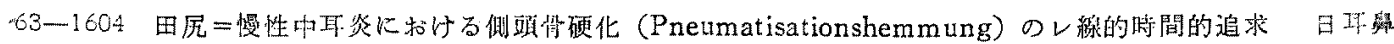

表 $16 の 4$ 狢村 $8(24.8 .4$ 生) 慨往症：特になし

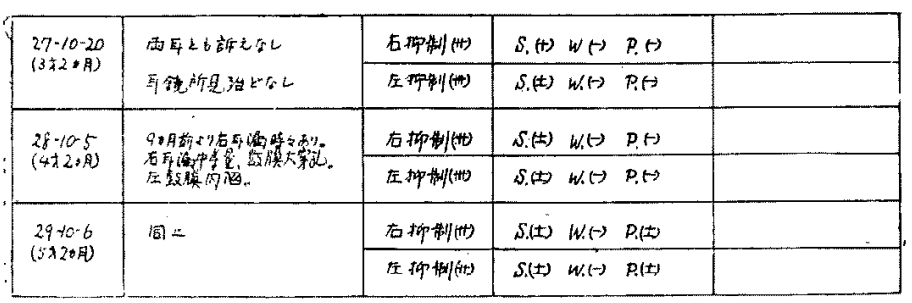

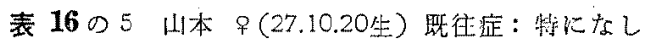

\begin{tabular}{|c|c|c|c|c|c|c|}
\hline \multirow{2}{*}{$\begin{array}{c}28-10-5 \\
(1+x)\end{array}$} & \multirow[t]{2}{*}{ 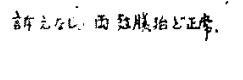 } & 右抑制( (1) & $S . \leftrightarrow w$ & $w \cdot t$ & 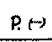 & \\
\hline & & 压抑籼(化) & $S \leftrightarrow \omega$. & $w(\leftrightarrow)$ & P. $\leftrightarrow$ & \\
\hline \multirow{2}{*}{$\begin{array}{l}29 \cdots 10-4 \\
(21)\end{array}$} & \multirow{2}{*}{ 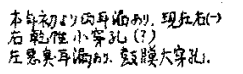 } & 右却制(t) & $S .( \pm)$ & $k^{\prime}(\rightarrow)$ & $P(t)$ & \\
\hline & & 厌神制( & $S$ (\#) $w$ & b. $\leftrightarrow$ & $P(t)$ & \\
\hline \multirow{2}{*}{ 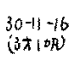 } & \multirow{2}{*}{ 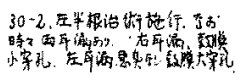 } & 古抑制(什) & $S_{(t)}\left(W_{1}\right.$ & $W_{(1)}( \pm)$ & $P( \pm)$ & \\
\hline & & 厌大斗街腰 & & & & \\
\hline \multirow{2}{*}{$\begin{array}{l}31-1 \mid-29 \\
(+x)=28)\end{array}$} & \multirow{2}{*}{ 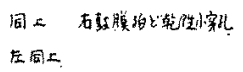 } & 古制做 & $S .(+) W_{.}$ & $W_{(}( \pm)$ & $p( \pm)$ & Sos 㧧大 \\
\hline & & 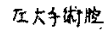 & & & & \\
\hline
\end{tabular}

快し，Pn は排制 $(+) \rightarrow$ 良好 $(+) \rightarrow$ 良好 $(+) \rightarrow$ 良好 $(+)$ $\rightarrow$ 良杍 $(+)$ と良好度增している。各蜂倮につる見る と, $\mathbf{S}$ は, $(+) \rightarrow(+) \rightarrow(+) \rightarrow(+) \rightarrow(+)$ と同程度なる

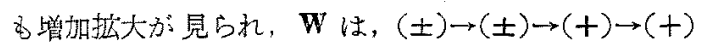

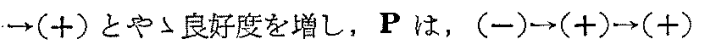
$\rightarrow(+) \rightarrow(H)$ とかなり良好度を增している。

〔症例2〕る，細 3 子時上り右耳漏特時あり，他に特

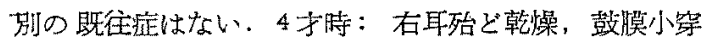

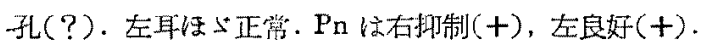
5于時: 右耳漏少量, 鼓膜小等孔. 左耳汪5正常. Pn

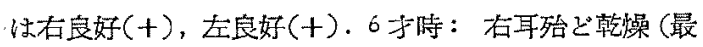

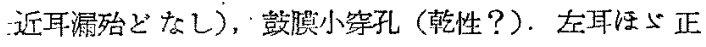
常. Pn 怯右良好 $(H)$, 左良好 $(t+)$. 即占, 2 年の経過 期間を通じ，右耳は，O.m.c.で，耳漏断続的（酦膜小

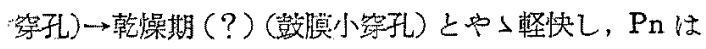
抑制 $($ 十 $\rightarrow$ 良好 $($ 十) $\rightarrow$ 良好 $(t)$ と, 著明化良好度を增し

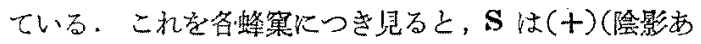
b) $\rightarrow(+)$ (䗋窝解明) $\rightarrow$ (H) (非常に拡大)，W は，(一)

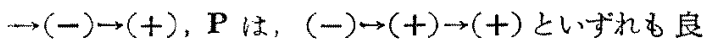
好造が增している。压耳はは心゙正常で，Pn は良肞(十)

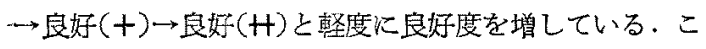
れを各跭笨につき見ると， $\mathbf{S}$ は $(H) \rightarrow(H) \rightarrow(H)$ と殆 ぞ不変, W (H) 上軽度に良好度を增している。

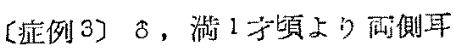
漏時時あり，現在は柰い、他に特別の 既往症はない，2方5月月時：右耳 湿潤, 期膜軽度発赤, 小穿孔㐫り(?),

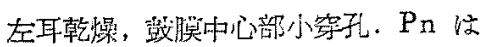
右抑制(H)，在抑制(H).2才9\%月

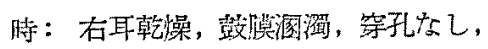
吉耳漏中等量, 豉哭高度 発赤穿孔.

Pn は在抑制(H)，左㧕制 $(H) ， 3$ 才

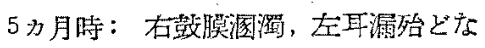
し(時内ありという)，鼓膜中等大驾 孔. Pn 注右抑制 $(H)$, 左排制(H). 4北5月月時：右耳谙変なく，左耳は

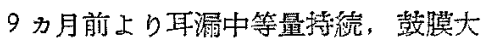
穿孔. Pn は右抑制 $(H)$, 左抑制 $(H)$. 4 于9 月月時：宥半根治術を施行せる

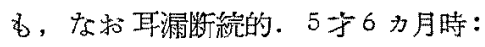
右耳著变なく, 左耳漏中等量, 顽償大 哿孔. Pnは右抑制(H)，在抑制(H).

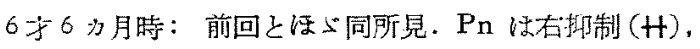
左抑制 (H). 即b， 4 年の経過期間を通し，右耳心，中

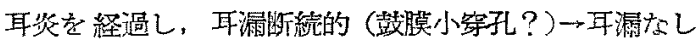

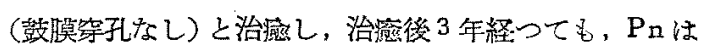

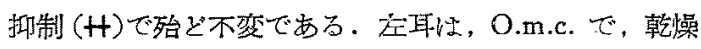
期 (耳漏断続的, 鼓膜小穿孔) $\rightarrow$ 耳漏断続 (鼓膜中等大穿

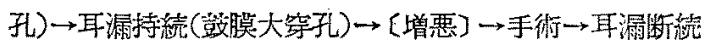
之経過し，Pn は抑制 $(H) \rightarrow$ 斯制 $(H) \rightarrow$ 抑制 $(H) \rightarrow$ 紟制

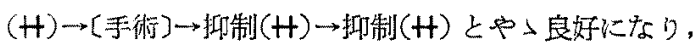
手術後も不变である。こ扎を、各峰窗につき見ると，右 耳で, S $( \pm) \rightarrow( \pm) \rightarrow( \pm) \rightarrow(-) \rightarrow(+) \rightarrow(+), \mathbf{P}(-) \rightarrow(-)$

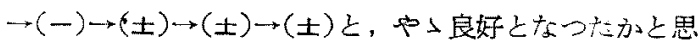
われる程度, 左耳では, $\mathbf{S}$ は (一) $\rightarrow(-) \rightarrow(-) \rightarrow(一) \rightarrow$ $[$ 手葕 $] \rightarrow(+) \rightarrow(+), \quad \mathbf{W}$ : $(-) \rightarrow( \pm) \rightarrow( \pm) \rightarrow( \pm) \rightarrow$ [乎術] $\rightarrow( \pm) \rightarrow( \pm), \quad \mathbf{P}$ : $(-) \rightarrow(-) \rightarrow-\rightarrow( \pm) \rightarrow$ [乎術 $) \rightarrow(+) \rightarrow( \pm)$ 上, や小良好に应つてい。。

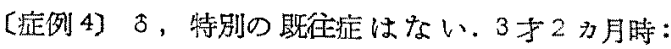
耳科的訴党なく，又耳鏡所見す正常。この時のPn 住右

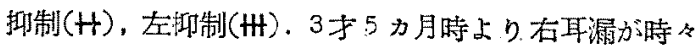
あるよ5になつた。4才 2 力月時：右耳漏中等量，鼓

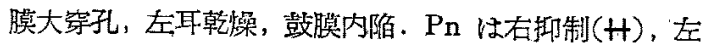

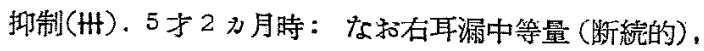

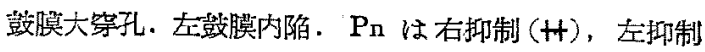




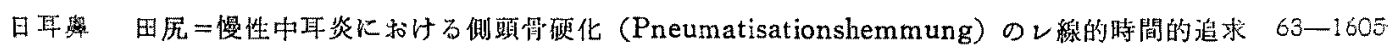

(十). 即ら， 2 年間の経過を通じ，右耳は正常より 0.

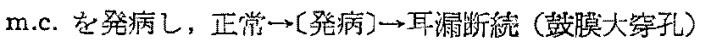
と変化し, Pnは抑制(H)のま〉殆ど变化が婎めらない。 各蜂㮤につき署ると, $\mathrm{S}$ は $(+) \rightarrow[$ 発病 $] \rightarrow( \pm) \rightarrow( \pm)$, $\mathbf{W}$ は $(-) \rightarrow[$ [発病 $] \rightarrow(一) \rightarrow(一), \mathbf{P}$ は $(-) \rightarrow[$ 発病 $] \rightarrow$

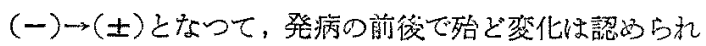
ない，在耳性全期間正常で，Pn は抑制 (H) 力35抑制

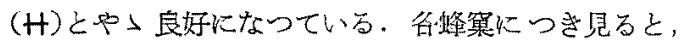
$\mathbf{S}$ は $( \pm) \rightarrow( \pm) \rightarrow( \pm), \quad W$ \& $(-) \rightarrow(-) \rightarrow(-), \quad \mathbf{P}$ は $($ 一) $\rightarrow($ 一) $\rightarrow( \pm)$ 上小良好になつているかといら 程度である。

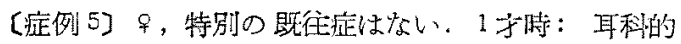

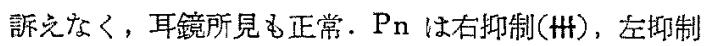

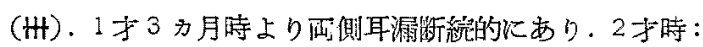

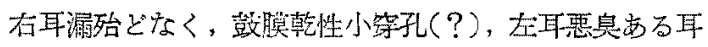

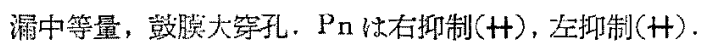

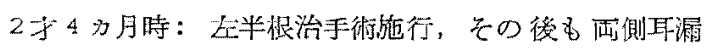

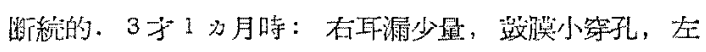

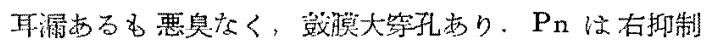

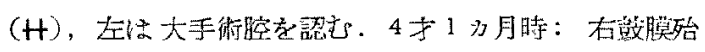

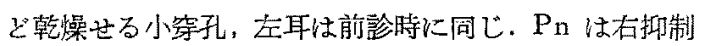

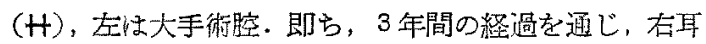

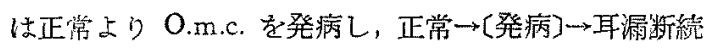

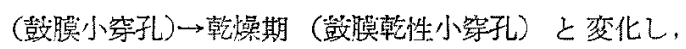

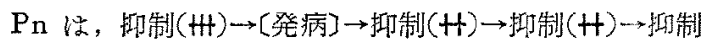

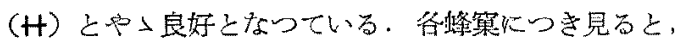

$\mathbf{S}$ H $(-) \rightarrow[$ 発病 $] \rightarrow( \pm) \rightarrow(+) \rightarrow(+), \mathbf{W}$ \& $(-) \rightarrow$ (発病 $] \rightarrow(一) \rightarrow( \pm) \rightarrow( \pm), \mathbf{P}$ 位 $(-) \rightarrow[$ [発疬 $] \rightarrow( \pm)$

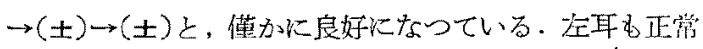

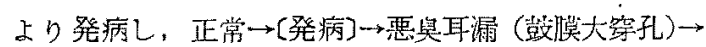

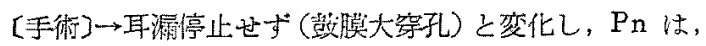
抑制 $($ H $) \rightarrow[$ 発病 $] \rightarrow$ 抑制 $($ H $) \rightarrow$ 手術腔亡なつている. 各

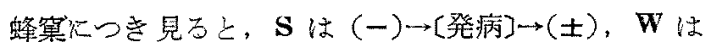

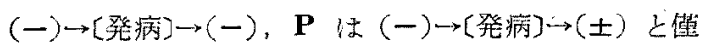
かに息对飞なりている。

\section{IV. 考按}

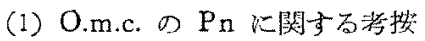

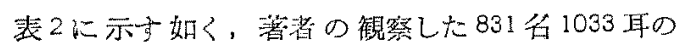
O.m.c. $\odot$ Pn は, 㧕制 (H) $45.4 \%$, 同 (H) $31.3 \%$, 同 $(t) .10 .5 \%$, 良好 $(t) 5.3 \%$, 同 $(H) 4.8 \%$, 同 $(H)$

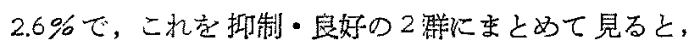
抑制 $87.2 \%$ ，良待 $12.8 \%$ となる。即ち良好磁著しく 少い.これは，正常耳に拈ける良好群の，Körner の
64.8, Schwarz の78.5, 下田の 50, 山下の56, 未光の 53 , 後藤孝授の 85.5 に比し，箸明に低くなつていること は，他の O.m.c.の科尌と一致している，乙かし，他の O.m.c.の統計，たと夫ぱ林のそれ(昭和11年より17 年までの O.m.c. 1096 耳を刘象としている）之比較し

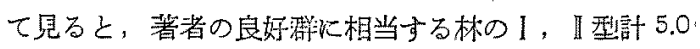
$\%$ ，抑制碚红相当与る【，N型部 $95.0 \%$ に比して，著

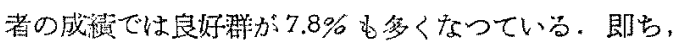

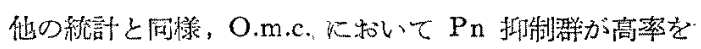

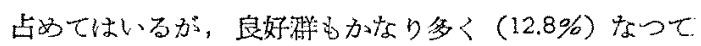

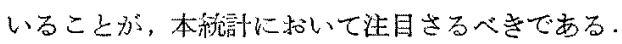

者者の秒計性昭和 23 年以降の O.m.c. 対象として

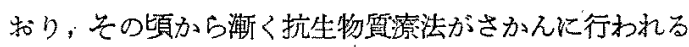
ようになつた事奏があるので，Pn 良好の\%を各年度

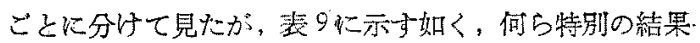
得られなからた。

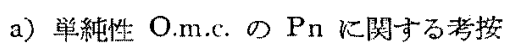

単紌性 O.m.c. は910耳で, 全O.m.c.D88.1\%を占

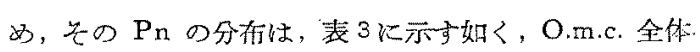
としての秋と代同じ数值を示している.

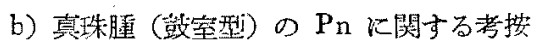

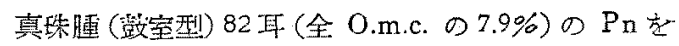
罗ると，表 4 に示子姐く，抑制(H) $48.8 \%$ ，同 $(H)$ $37.8 \%$, 同 $(+) 4.9 \%$, 良好 $(t) 3.7 \%$, 同 $(H) 3.7 \%$,

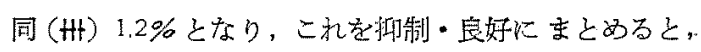

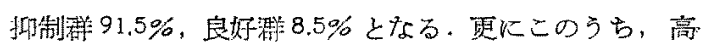
度抑制群仗 $86.6 \%$ ，高度良灯缽は $4.9 \%$ となる。

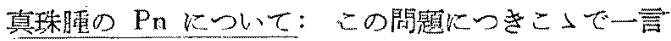

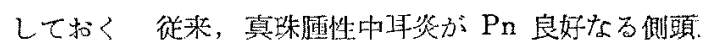
骨に起つた例禹報告されてはいるが（Berberich，Mayer)，乙九机它しろ例外で，真珠逨性中耳炎はPn.H 高

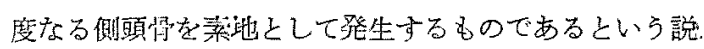
(Wittmaack)，が一般隹めら訊ているようである。

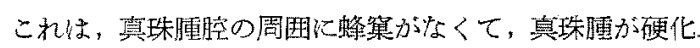
した骨壁をあつて囲まれていることを意制している。し

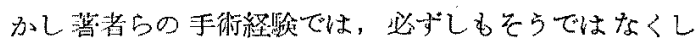
て、真蛛朋空の周囲以蜂案が見られることもしばしばで

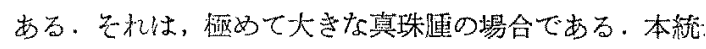
計に出いて，真珠腫にして Pn 良好なる 例が7例罗ら れ，特に天のうち1例保，Pn 極めて良好な例でする。 この例は，真跦腄が Aditusに局在していた例で，その 化のP Pn 良好例は，いずれる真珠腫が Aditus 附近に 止まつていた例である・後藤䓔授は，これを初期真珠腫 


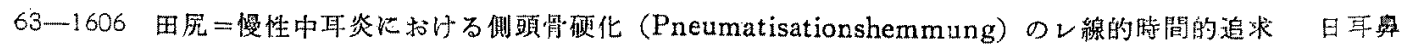

(beginnendes Cholesteatom) と呼んでおる。これら の例は、㭙を経れば、いずれも極めて大きな真珠控を形 成方西もの之思われる，元来真珠䐈の大さは，その発生 “舟体のPn K上り篓件づけられているものであつて, 極めて小さい真珠腫は Pn-H の極めて強い側頭骨に発 生したものである，この意陎から真珠腫のPn を論ず れば，大なる真珠腫腔安示症例怯，Pn 良好と見做さ なければならないしかし本観察に捣いては，一応真珠

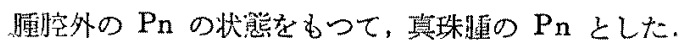

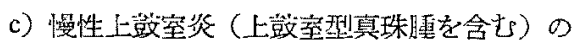
Pn k関する考按

㨋者らは，いわゆる単純性慢性上鼓室炎の大部分の例 吐，上鼓室型真珠腫性のものであると思つている。しが て西者の正確な轞別は，手術によつて始めて可能になる ことであって，耳鏡的及び「レ」線的な観察では，两者 を明確に鑑別することは困難である。促つて，本絖計に

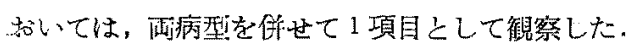

この疝病型を作せた 1 洋のPnは，表4 亿示卞如く， 総数 41 耳（全 O.m.c. の4.0\%) の5ち, 卲制(H) 39.0 $\%$, 同 $(+$ H) 29.3\%, 同 $(+) 7.3 \%$, 良好 (十) 7.3\%, 同 (H) $12.2 \%$ ，同 (卅) $4.9 \%$ でこれを抑制・良好の2 澼 にをとめると，北制学 $75.6 \%$ ，良好群 $24.4 \%$ となる。

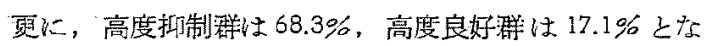
る.

即台，O.m.c.を，各のP P 抑制度の高い方から順に 举げると，真珠腫（㩆室型，91.5\%)，曾純性 O.m.c. (87.4\%)，上鼓室化膿 $(75.6 \%)$ となり，特炕真珠腫は 高度抑制群 $86.6 \%$ に上る。これに対し，上放室化䜨は Pn 良好度 $24.4 \%$ ，特にその高度良好群は $17.1 \%$ に上 万.

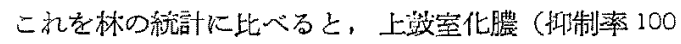
$\%$ ), 真珠腫 (同 99.4\%), 単純性 O.m.c. (93.3\%) 之 恃全く順序が異なり，全病型を通じて抑制率が低く，特

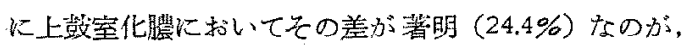
本絖計に括いて注目される。

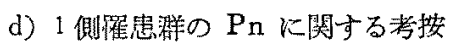

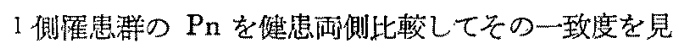
ると，表 5 に示さ礼る如く，24.8\%である.これは，表 18 に示夺諸家の正常耳に関すPn 万一致度に比べて峦 しく低くなつている・よつてこれを抑制・良好の2 㵙に まとめて見ると，表6に示す如く，一致度は $47.0 \%$ と なる.表18に記した林の一致度は，1側罪患洋・両側 犀患群を通じての数字で! 側惟患詳のみの一致率として

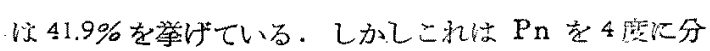

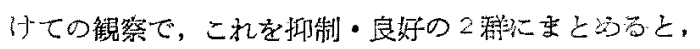
任ぶ著者の一致率々相等しくなる。

表 17 両耳のPnの比较(正常耳) (後藤敏郎教授による)

\begin{tabular}{|c|c|c|}
\hline $\mathrm{P}_{n}$ 美口程度 & 数 & $\%$ \\
\hline 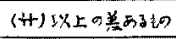 & 29 & 6.5 \\
\hline (十)の量の3もの & 74 & 16.6 \\
\hline 座与きもの & 34.2 & 76.9 \\
\hline 污 & 445 & 100.0 \\
\hline
\end{tabular}

表 18 雨耳一致度の純計

\begin{tabular}{|c|c|c|c|}
\hline 趣告意 & $\%$ & 例数 & 猢象。 \\
\hline Turner u. Porter & $8 \delta$ & 880 & \\
\hline Talpis uLiehcrmann & 74.2 & 69 & 正 \\
\hline Beck & 70 & $Z$ & 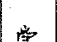 \\
\hline 後䇎(敏) & 76.9 & 445 & $p$ \\
\hline Steurer & $7 / 5$ & 527 & 耳 \\
\hline 茳 & 70.0 & 2 & \\
\hline 林 & 51.4 & 459 & 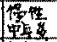 \\
\hline 黑. 田 & 61.2 & 63 & 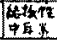 \\
\hline
\end{tabular}

表 19 正常耳のPnの\% (後能教授以上る)

\begin{tabular}{|c|c|c|c|c|c|c|}
\hline \multirow[b]{2}{*}{$\operatorname{Pn}$} & \multicolumn{3}{|c|}{ 良恏 } & \multicolumn{3}{|c|}{ 拈 制 } \\
\hline & $+\pi$ & $\pi$ & + & + & $\pi$ & H \\
\hline 10 & 37,3 & 27.4 & 20.8 & 7.9 & 3.4 & 3.2 \\
\hline$\frac{1}{5}+$ & & 85.5 & & & 145 & \\
\hline
\end{tabular}

(奶鼠：成人 1000 年)

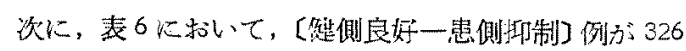
E: $=51.8 \%$ K上るの以従来の Pn-lehre の理論に台致七 ているが， 7 耳=1.1\% の率で〔位側抑制一患側良好〕例 が存在することは特注意せらるべきで，従涯のPn-lehre に全く合致しない所見で方る。これだけの例外の存 在することは，中耳然の慢性化に中耳のPn が㮒めて

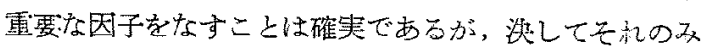
ではないことを示しているものと涪える。

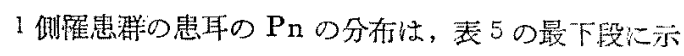
され、これは表2亿示されている O.m.c. 全体としての Pnの分布と，ほ心゙相等しい数値定している.

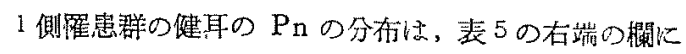
示され，これを抑制・良好の2 娜にさとめれば，抑制群 $34.7 \%$ ，良好群 $65.3 \%$ となる、これを，玨 19 に示され る正常耳のPn の分布，抑制群 $14.5 \%$ ，良好群 $85.5 \%$ に比べると，泖制洋が $20.2 \%$ あ高くなっている.. 淜制 


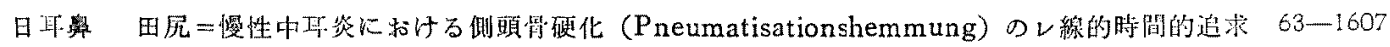

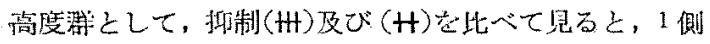

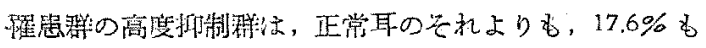

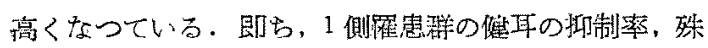
飞高度抑制率法; 正裳耳のそれk比して著しく高くなつ ていることが分る。

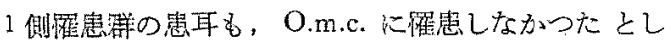

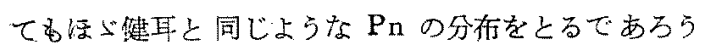
ことは，关18 亿批いて示さ礼万正常聂のPn の左台一 致度が，70ー88\%に上ることよりして，容易に推測さ

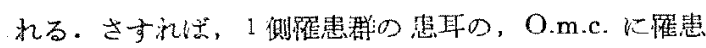
せさる状態に和す Pnは, 正常耳のPnに比して,

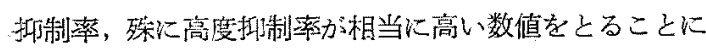

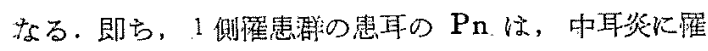
患せずとも，先天的体貿的にすでに抑制的傾向索有して いることが推定でさる。

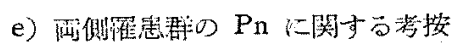

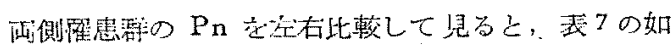

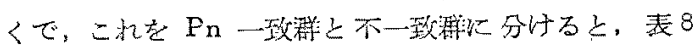
のA に示方如く，一敖群 $66.3 \%$ ，不一致群 $33.7 \%$ とな

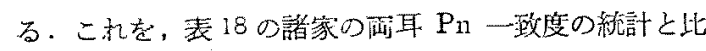

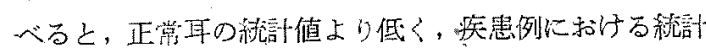
值よりる高くなつている。この一致滕を，Pn の程度ご とに総括すると，露 $8 の \mathrm{~B} の$ 如くなり，抑制群計は

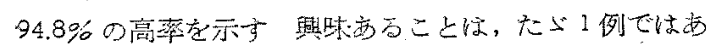
るが，活側 Pn 艮好(H) の例があことである。

更に，これを表 $2 の$ O.m.c. 全体としてのPn と此

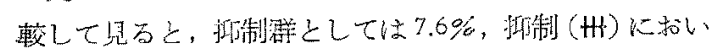

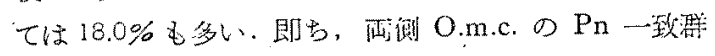
は，O.m.c. の中でも抑制度が最も進んでいるというこ とがでる。

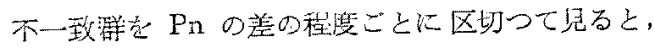
表80 C の期くなる。即方, 不一致とはいつても, 64.8\% 即方約 $2 / 3$ は1 度差付すきない。しか，5度差 が1例 (1.4\%)，4度差分4 例 (5.9\%) あることは，一 态注目すべきことである。

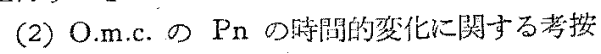

O.m.c. のPn の寺間的推移に伴なら変化索観察する

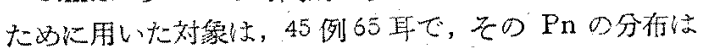
表 12 の如くで，これを総括的観察の対鲑とした 1033 耳のPn の分有に比すると，抑制(H) と同(H)の垎

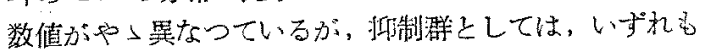
$87 \%$ 強となつて, 相等しい值を示している.

a) O.m.c. の病型の变化须い 洔間時間潭を抋いての O.m.c. の微察に際してはそ

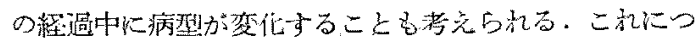

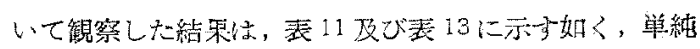

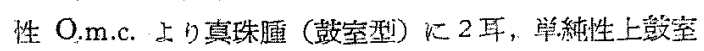

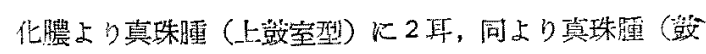

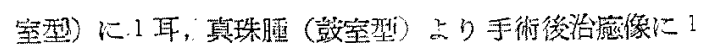
聑が，それ杂れ变化している。

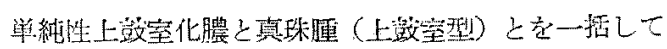

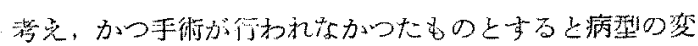
化したものは3耳になる。即占，65耳のるb，5.0\%以

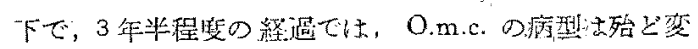
化していない.

b) 第 1 回微察時と第 2 回推察時とのPn の比校

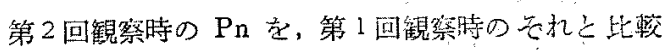

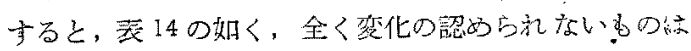

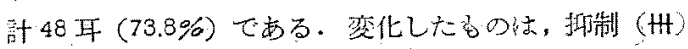

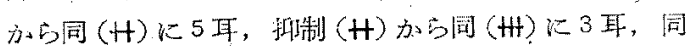

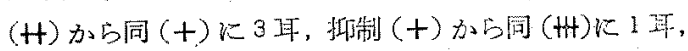
同 (十)から同 (H)に3耷, 計 15 耳 (23.1\%)である。

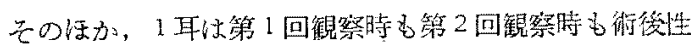
澄明像克呈し，2耳は新しく術後性澄昭像を呈した。良

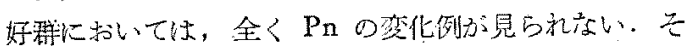
こで，その変化の程度が(十)程度のものでも，抑制度の 進行したものと，良好度の進行したものとに委々かて見

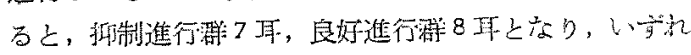

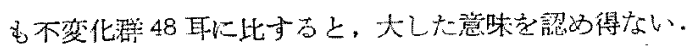

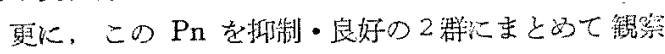

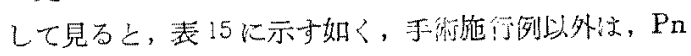
の変化は全く認められない。

この事害よりして，最短1年，最長10年4\%月，平

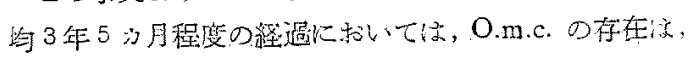
側頭骨のPnの艮好をきたすとは勿帮いえないが，同

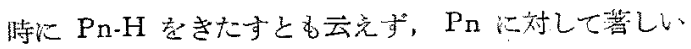
变化を与定ない上見做される。

(3) 乳妙児について O.m.c. の発庭初期からの

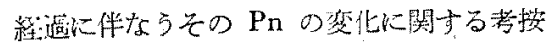

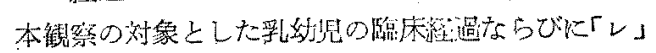
線像所見を琴的して見ると，

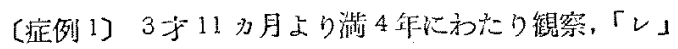

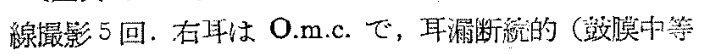

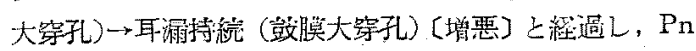
は抑制（H）のま入不变. 左耳はO.m.c. 経過で，耳漏

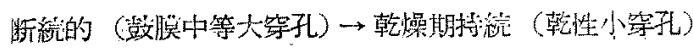




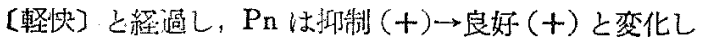
ている。

〔症例 2〕4オ゙より渶 2 年にわたり钼察、「レ」踪撮影 3 回. 右耳注 O.m.c. で，耳瀮断続的（政膜小第孔） $\rightarrow$

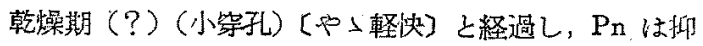
制 $(+) \rightarrow$ 良好 $(t+)$ と变化している。左耳忹中耳炎なく， Pn 汇良好 $(H)$ のま入不変である。

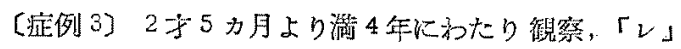

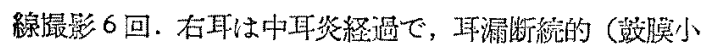

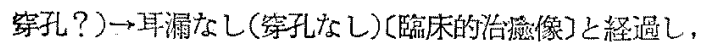
Pn 以抑制(H)程度で殆ど不変. 左耳隹 O.m.c. で, 乾 蜗期 (鼔膜小穿孔) $\rightarrow$ 耳漏断絖 (中等大穿孔) $\rightarrow$ 耳漏持繶

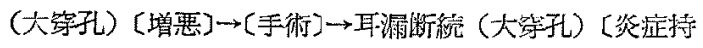

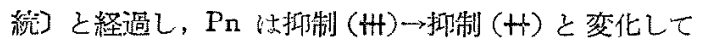
いる.

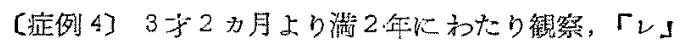
線撮影 3 回. 右耳心 O.m.c. 発病で, 正常 $\rightarrow$ [発病] $\rightarrow$ 耳

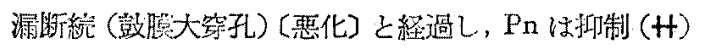
のまっ不变である。左耳は中耳竾なく，Pn は抑制 (H) $\rightarrow(H)$ と恋化している。

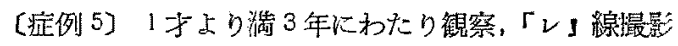
4 回. 右耳は O.m.c. 発病で, 正常 $\rightarrow[$ 発病] $\rightarrow 耳$ 漏断繶

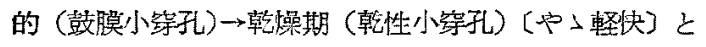

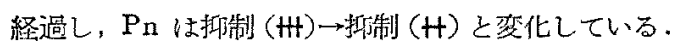

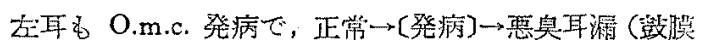

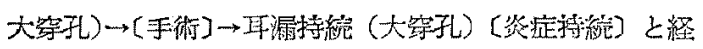
過し, Pnは抑喇 $(H+$ H $\rightarrow$ 抑制 $(H) \rightarrow[$ 手術 $] \rightarrow$ 手術腔と 変化している。

以上5各10耳の5号，O.m.c. であつた8耳につき考

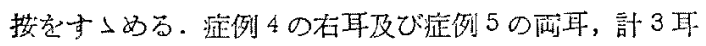
は，第 1 回「レ」線撮影後，O.m.c. 発病せる例で， 貴電なる症例である。他の 5 耳はいずれも，O.m.c. 発 病後から「レ」線的追求をはじめている。

発病前よりの篗繁例 3 耳の弓占, 症例 4 の右耳のPn は，発病の前後いずれも抑制（H)で不变である。症例 5 の届耳は，発病前 $\mathrm{Pn}$ 抑制 $(H)$ 力口 発病後抑制 $(H)$ と、牙し万良好々なっている.即古，O.m.c. 老発病して も，Pn は不变か，的しろ良好度が進行している。

発病後钼察例 5 耳の弓号, 途中浩瘵像を示した症例 3 の右耳が全経過中 Pn 抑制 (甘)程度であるに対し，左 耳は途中手術を行うほど增恶したにも拘らず，手術前ま

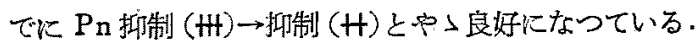
可に，增悪炎きたした症例1の右耳，Pn が全観察期
間抑制（H）のま」不变であるに対し，軽快像を示した

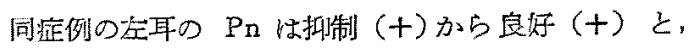

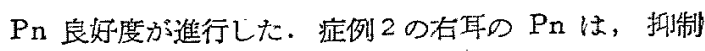

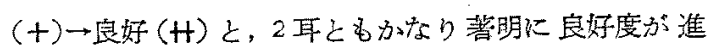
行している.

即ら，O.m.c. 発病前より覞察した了耳のうら，1耳は 発病前後で Pn 不変, 2 耳《倬か㤽好度を增し，その

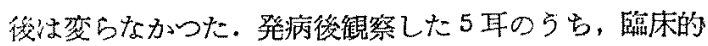

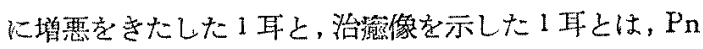
抑制（サ）のま上不变で，手術を要するに至つた1.耳は，

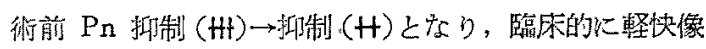
を示した 2 耳のPnは，ふなり著明に良好度を增した。

即ち, 5 症例 8 耳についての钼察では, O.m.c. 発病前

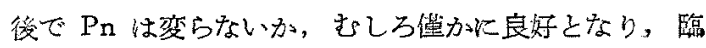

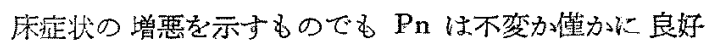
となり，轻快像定示寸例では，Pnはかなり䈐奛に良好 となつたＰＰの抑制度の進行した例は1例も見られな かつた.

\section{V. 総括及び結語}

（1）昭和 23 年以降昭和 34 年要での O.m.c. 虫者831 名, 1033 耳の「レ」線像を観察し, 次の結果圭得太。

i) O.m.c. の病型は, 筝純性 O.m.c. $88.1 \%$, 単純性

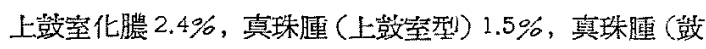
室型） $7.9 \%$ )であつた.

ii) O.m.c. 全体と乙てのPn P分布活，泖制 (H) $45.4 \%$, 同 (H) $31.3 \%$, 同 (t) $10.5 \%$ ，良好 (t) $5.3 \%$ ，同 (H) 4.8\%，同 (泝) $2.6 \%$ であつた。長好洋 としてまとめると，12.8\%となりこの数値は戦前の綕 計の々れに比し，相当高くなつている.

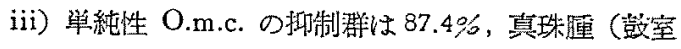

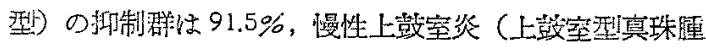

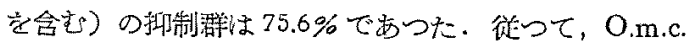
の病型を，它の抑制率の高度なもの上り順に举げると，

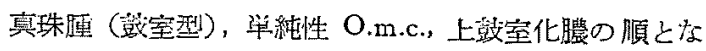
り，従氿の統計と暴なつた順になつた・特に上鼓宝化膜 に执いて，Pn 良好箱が $24.4 \%$ にることが，従来の 維計と著しく買なつた。同時に，慢性上鼓室化膿之真珠 堙（上䰚室型）とはレ䠌的には1病型として観察すべき であるとした。

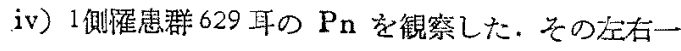

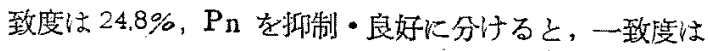

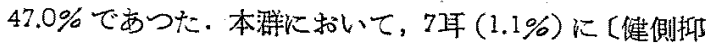
制一患側良好う例が見られることに注目した。 


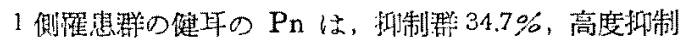
群 $24.0 \%$ ですつた，この値起，正常耳のPnと此較し，

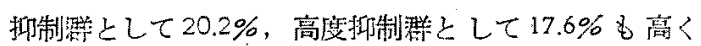
なつている事奏及び正常耳の Pn の在右一致度が70

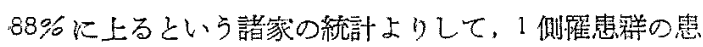
耳のPn は，中耳炎櫵患以前に扎いて，既先天的体

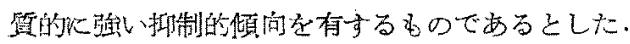

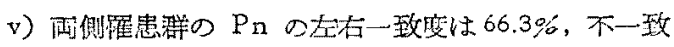

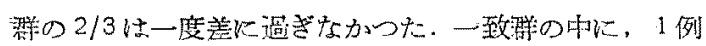
車側 Pn 良好 (卅) 例が見られた。

(2) O.m.c. 患者 45 名65耳支，平均 3 年5 力月の间 嗝を和いて，2回観察乙，次の結果を得た。

i）䍶純性上鼓室化膿と真珠霾（上鼓室型）とを伊せ て1病型として考えると，病型の変化したすのは，3耳 (4.6\%)であつた.

ii) 前後 2 回の䋩察時のP Pn 比較して見ると，全く

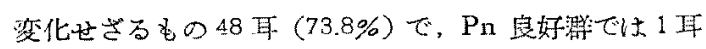
6Pn の变化を見なかつた.Pn の变化の程度か（十） のものでるすへてて变化したものとしてまとめると，抑制 進行群 7 耳, 良好進行群 8 耳であつた。しかし，Pnを

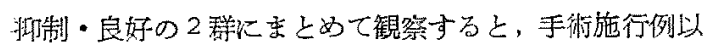
外, Pn の変化江全く認められなかつた。

以上上りして，O.m.c. の䘽察期間が平均 3 年 5 カ月 程度では，側頭骨の硬化は見られなかつた。

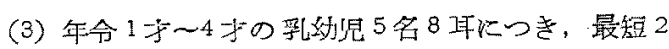
年, 最長 4 年にわたり，それぞれ3回〜6回の「レ」線 撮影を行い, 3 耳.儿ついて佂 O.m.c. 発淀前上り，5耳 比いては発症後上り, Pn の变化を钼察し, 次の結果 老得た。

O.m.c. 発症の前後で，Pn は変らないか，むしろ嚾 か长良好となり，臨床症状の增悪を示寸例でも，Pnは 不変か，あるいは僅か心良好となり，軽快像を示す例で は，Pn注かなり著明に良好となつた。全例を通じ，Pn の卯制度の進行した例は1例る見ら机なかつた。

\section{文献}

1) Wittmaack: Über die normale und die pathol- ogische Pneumatisation des Schläfenbeines. Gustav Fischer, Jena, 1918, 2) Derselbe: Zur Frage der Bedeutung der Mittelohrentzündung des frühesten Kindesalters für später, A.f.O. Bd. 129, 1931, S. 14. 3) Derselbe: Cholesteatombildung, Pneumatisation und Pneumatisationslehre von Wittmaack. A.f.O. Bd. 125, 1930, S. 218 . 4) Derselbe: Schleimhaut- konstitution und Preumatisation. A.f.O. Bd. 132, 1932, S. 261.5 5) Mittermaier: Zeitschr. f. H.usw. Heilk. Bd. 45, 1939. ,6) Kinck u. Witte: Röntgenologische Studien über die Entwicklung der Warzenfortsatzzellen nach Otitis media im ersten Lebensjahre. A.f.O. Bd. 119, 1928, S. 128.7 7) Barth: Studien über die Anatomie, Entwicklungsgeschichte und normale Pneumatisation der menschlichen Schläfenschuppe. Z.f.H.N.O. Bd. 26, 1930 , S. 483. 8) W. Albrecht: Wie weit kommen konstitutionelle Probleme für pathologische Vorgänge im Ohr und an den oberen Luftwegen in Betracht. Z.f.H.N.O Bd. 29, 1931. 9) Derselbe: Pneumatisation und Konstitution. Z.f.H.N.O. Bd. 10, 1924. 10) Belinoff u. Balan: Über den Bau der Pyramidenspitze. M.f.O. 64. Jg. 11) Körner: Über ein topographisches wichtiges Verhätnis am Schläfenbein Z.f.O. Bd. 22, $1936 . \quad$ 12) Schwarz: Die Bedeutung der hereditären Anlage für die Pneumatisation. Arch. f. O. Bd. 123, $1929 . \quad 13$ ) Altschul: Beitrag zur Röntgenologie des Gehörorganes. Z. Hals-usw. Heilk.. 14, 1926.1 14) E.G. Mayer: Otologische Röntgendiagnostik. Handb. d. Röntgenkunde, II Bd. $1930 . \quad$ 15) Steurer: Das Röntgenbild des Warzenfortsatzes und seine klinische Bedeutung. Z.f.H.N.O. Bd. 12, 1925, 16) 後藤 (敏): Pneumatisation の成立と之の臨床, 日开

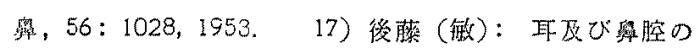
$\mathrm{X}$ 楾写真の撮り方已兒方，隐放，1:2，4，6号，1956. 18) $K$. Yamashita: Über die Schläfenbeinzellen.

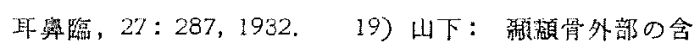

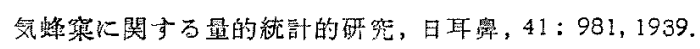

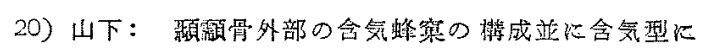

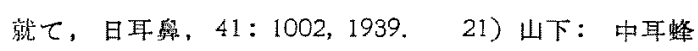

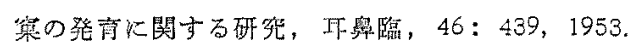

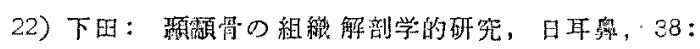

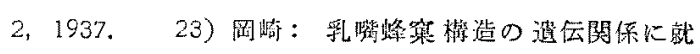

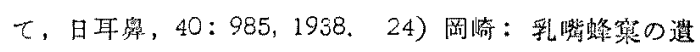

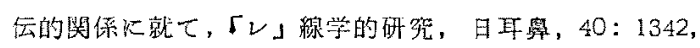

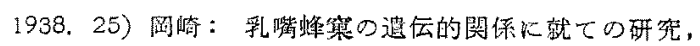

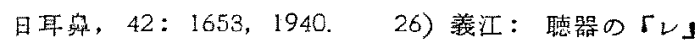
学的研究 (其一), 急性中四莰並に急性乳嘴突起炎の 「レントケ゚ン」学的研究, 日焣奥, 37：1265, 1935. 


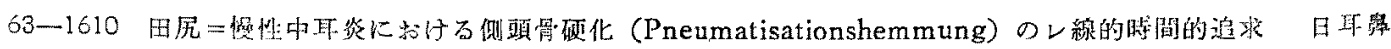

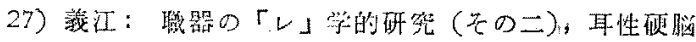

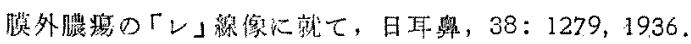

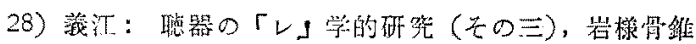

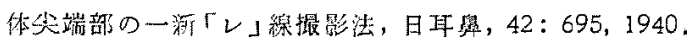

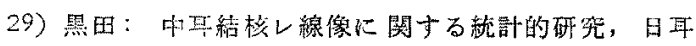

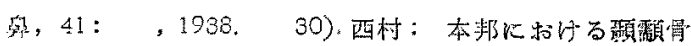

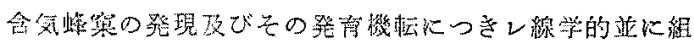

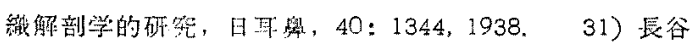

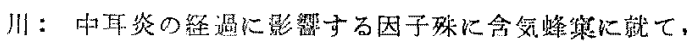

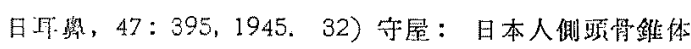

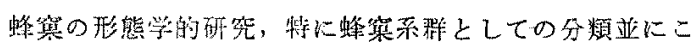

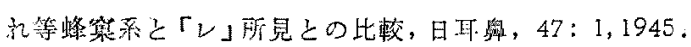

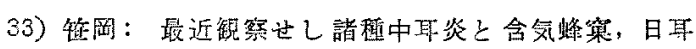

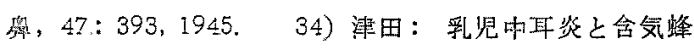

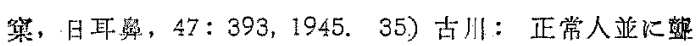

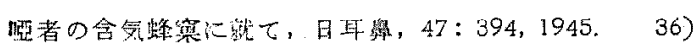

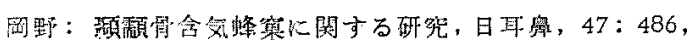

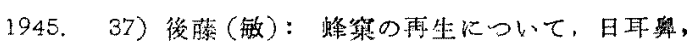
49: 1946. 38) 捘蔯 (敏)：再び惵案の再生について, 耳舅咽，20：13，6号：３9）吉見「「上」線影像に上

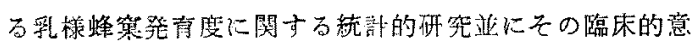

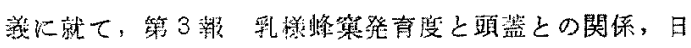

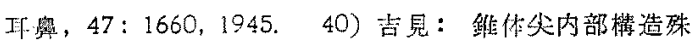

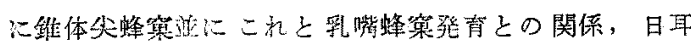

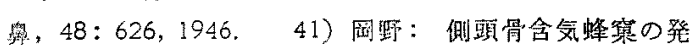

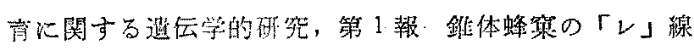
学的研然，日早率，49: i112，1947.42）上田：所謂

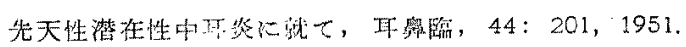

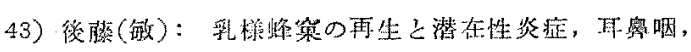

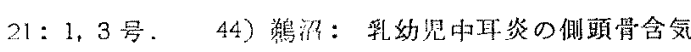

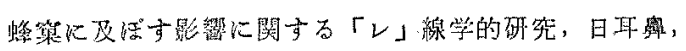
54: 19.4，223，1951.45）林：僈性中正炎の侧頭骨含

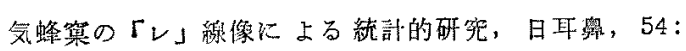

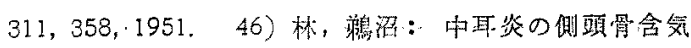

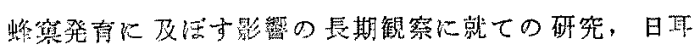

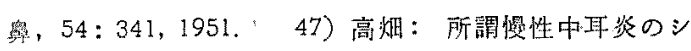

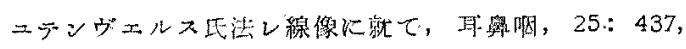

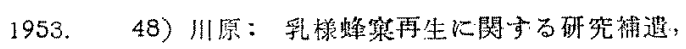

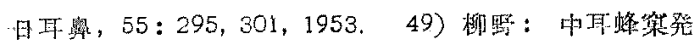

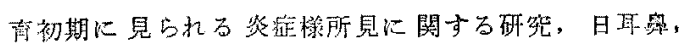
$56:{ }^{5} 56,942,1954$.50) 小林: 中耳: Pneumatisation

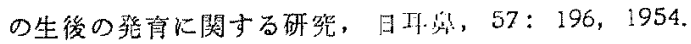
51) 不破, 小林, 光增, 村島: 中年 $\mathrm{Pn}$ の発育々全身

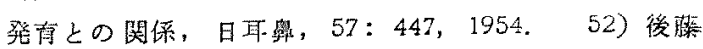

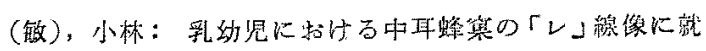

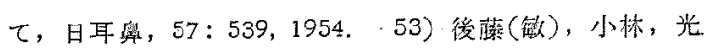

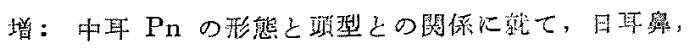

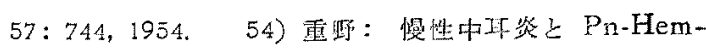

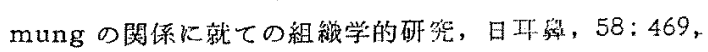
1955. 55) 重野：慢性中臣炎之側葓骨の硬化，日耳

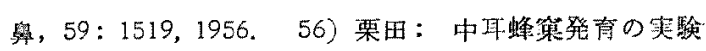

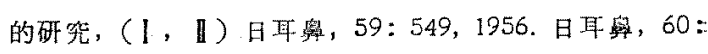
205, 1957. 57) 後滕, 海江田: 中耳力》ルと Pneu-

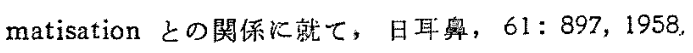

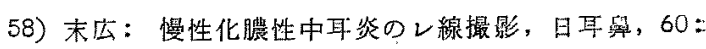

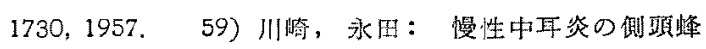

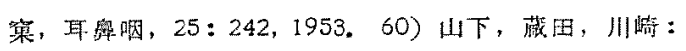

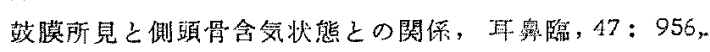

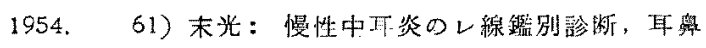
臨, 49:909, 1956. 62) 侁荻, 大木, 米山, 千萡:

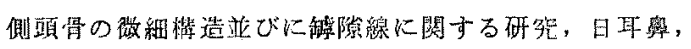
$62 ： 22,1959$.63) 高畑：乙線像上り見た経外正道的

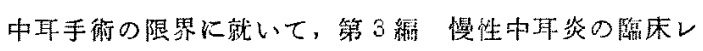
線学的研究, 日耳䋰, 61:278, 1958. 64) 松永, 福 中：慢性中耳炎患者 Pneumatisation の統棓的観察, 日耳舆，61：333，1958.65）坂口：慢性中耳炎上含

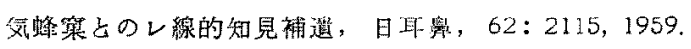

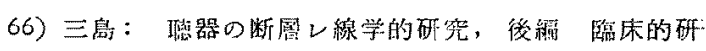

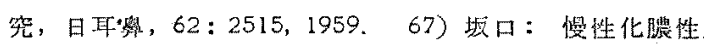

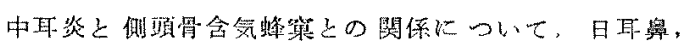

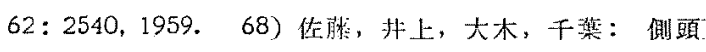

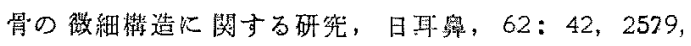

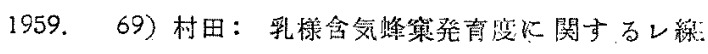
学的考察, 日耳鼻, 62:2645, 1959.

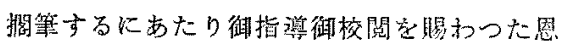

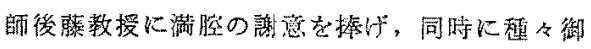

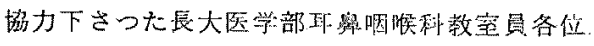
に深く感謝士る。

（原稳到薄二昭和 35.2.10日） 